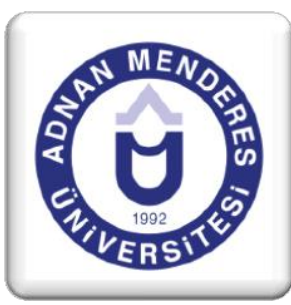

\title{
Kamu Sağlık Harcamalarının Etkililiği: Panel Veri Analizi
}

Gülizar Seda YILMAZ ${ }^{1}$, Sacit Hadi AKDEDE ${ }^{2}$

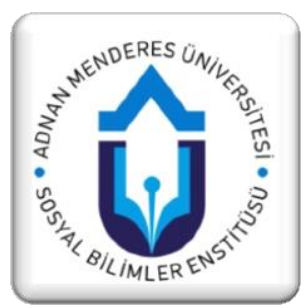

\section{ÖZET}

Bu çalışma kamu sağlık harcamaları ve beş yaş altı çocuk ölüm oranı ile ölçülen sağlık sonuçları arasındaki ilişkiyi ve düzenleyici kalite indeksi ile ölçülen yönetişimin kamu sağlık harcamalarının etkililiğini belirlemedeki rolünü incelemektedir. Kamu sağlık harcamalarının etkililiği, sağlık üretim fonksiyonunun 149 ülkeye ait 20022012 yılları verisi ile incelenmiştir. Çocuk ölüm oranı üzerinde kişi başı GSYİH, kadın eğitim seviyesi, gelir eșitsizliği, çevresel sağlık ve demografik yapının etkileri daha önceki çalışmalarla benzerlik göstermektedir. Sonuçlar iki önemli bulguya işaret etmektedir. İlki, kamu sağlı harcamaları çocuk ölüm oranını açılamakta diğer sosyoekonomik ve çevresel sağlığa ilişkin değişkenlere göre zayıf kalmaktadır. İkincisi ise, kamu sağlık harcamalarındaki artış çocuk ölüm oranlarını, kamu kesiminin piyasayı düzenleyici kalitesinin yüksek olduğu ülkelerde düşürmektedir. Daha genel ifadeyle, kamu sağlık harcamaları sağlık sonuçlarını iyileştirmede yönetişim seviyesi yüksek ülkelerde daha etkilidir.

Anahtar Kelimeler: Kamu sağlık harcamaları, çocuk ölüm oranı, yönetişim, düzenleyici kalite, panel veri.

\section{The Effectiveness of Public Health Expenditures: Panel Data Analysis}

\section{ABSTRACT}

This paper examines the links between public health expenditures, and health outcomes- measured by the rate of child (under five) mortality and it also investigates the role of governance, measured by regulatory quality, on the effectiveness of public health expenditures. The effectiveness of public health expenditures is examined within health production funciton by using 2002- 2012 data across 149 countries. Our empirical results Show that the effects of GDP per capita, female education level, income inequality, environmental health and demographic structure on child mortality are similar to those in previous studies. Results indicate two important findings. First, public health expenditures remain weak to explain child mortality rate when compared to other socioeconomic and health-related variables. Second increase in public health expenditures is associated with reduced child mortality just in countries where regulatory quality is high. More generally, public health expenditures become more effective in improving health outcomes in countries with high governance level.

Keywords: Public health expenditures, child mortality rate, governance, regulatory quality, panel data.

\footnotetext{
1 Arş.Gör., Adnan Menderes Üniversitesi Nazilli İ̈BF Maliye Bölümü.

${ }^{2}$ Prof.Dr., Adnan Menderes Üniversitesi Nazilli İIBBF Maliye Bölümü.
} 


\section{Giriș}

Üretim ve tüketimi dışsallık yayan eğitim, sağlık gibi kolektif niteliği yüksek yarı kamusal malların, piyasa tarafından eşit sunulamaması ve finansmanına katılamayanların dışlanması devletin sağlığa müdahalesini gerekli kılmaktadır. 1950'ler sonrası uluslararası kuruluşların da çağrılarıyla, sağlığın küresel kamusal mal olarak değerlendirilmeye başlanması, devletlerin, kalkınmanın en önemli göstergelerinden biri olarak bu alana yaptığı harcamaları dönem dönem politika farklılıkları olsa da artırmıştır. Bu noktada, artan kamu sağlık harcamalarının, doğumda yaşam beklentisi, bebek ölüm oranı, beş yaş altı çocuk ölüm oranı gibi sağlık sonuç göstergelerinde iyileşme sağlayıp sağlamadığı sorusu önemli hale gelmektedir. Genel olarak Avrupa ülkeleri, sağlık harcamalarında kamunun payının en yüksek olduğu, aynı zamanda bebek ve çocuk ölüm oranlarının en düşük olduğu ülkelerdir. Ancak "kamu sağlık harcamalarının yüksek olması sağlık sonuç göstergelerini iyileştirir" gibi yalnızca bu iki değişkene ve belirli bir ülke grubuna göre bir çıkarım yapmak eksik bir bakış açısı olacaktır. Çünkü kamu sağlı harcamalarının etkililiği, ülkelerin gelir seviyesi, nüfusun eğitim seviyesi, çevre sağlığı ve kamu kesiminin performansı gibi farklı birçok faktörün de dahil olduğu analizler gerektirmektedir.

Beşeri sermayenin ve kalkınmanın temel unsurlarından biri olan sağlığa yapılan harcamaların sağlık sonuç göstergelerini iyileştirip iyileştirmediğini görmek, bu alanda devletin ne ölçüde etkili olduğunun ortaya konması, kamu harcamalarının etkililiğinin artırılması için getirilecek politika önerileri açısından oldukça önemlidir. Bu çalışmada literatürde yer alan çalışmalara göre daha geniş bir örneklem kullanılarak daha yüksek bir gözlem sayısına ulaşılmıştır. Kamu sağlık harcamalarının sağlık sonuçlarını iyileştirmedeki etkisini görmenin yanında, ülkelerarası farkların açıklanmasında literatürde görece daha az önem verilmiş kurumsal yapının etkisi de incelenmiştir. Kurumsal yapının kamu sağlık harcamalarının etkililiğindeki rolüne vurgu yapılarak, yönetişim seviyesi yüksek ülkelerde kamu sağlık harcamalarının daha etkili olacağ yönündeki hipotez test edilmiştir. Böylelikle, ülkeleri yalnızca gelir seviyelerine göre değil yönetişim seviyelerine göre sınıflandırarak yapılacak çalışmaların önü açılmış olacaktır.

Bu kapsamda öncelikle ikinci bölümde devletin sağlığa müdahalesinin gerekçeleri, iktisat teorisi açısından kısa bir tarihsel özet de sunularak değerlendirilecektir. Sağlık politikalarının ayrıntılı incelemesi bu çalışmanın kapsamında olmasa da üçüncü bölümde dünyada sağlık harcamalarında kamunun payının artışını görmeye yönelik olarak sağlığa ülkelerin bütçelerinden ayırdıkları paylar ve kamu sağlık harcamalarının milli gelire oranının yıllar içerisindeki değişimleri grafik ve tablolar yardımıyla incelenecektir. Dördüncü bölümde ise, beşinci bölümde yapılacak olan ekonometrik analize temel oluşturması açısından kamu sağlık harcamalarının sağlık sonuç göstergelerine etkisi ile ilgili literatür özetlenecektir. Beşinci bölümde, analizde kullanılacak olan değişkenlere ilişkin özet bilgiler, tanımlayıcı istatistikler ve modele yer verilerek, kamu sağlık harcamalarının etkililiğini görmek üzere panel veri kullanılarak yapılan tahmin sonuçları yorumlanacaktır. Altıncı bölümde ise sonuç ve öneriler yer alacaktır.

\section{Devletin Sağlıktaki Rolünün İktisat Teorisi Açısından Değerlendirilmesi}

Devletin sağlık alanında var olmasının gerekçeleri, sağlık hizmetinin yarı kamusal nitelikte olmasına dayanmaktadır. Hatta koruyucu sağlık hizmetlerinin, toplumsal faydası bireysel faydasından yüksek olması nedeniyle tam kamusal mal olarak düşünülebileceği savunulmaktadır (Yurdadoğ, 2007: 591). Dolayısıyla iktisat teorisi açısından devletin sağlıktaki rolünü incelemek, kamusal mallar teorisi üzerinden gerçekleştirilmektedir. 
Devletin sağlığa müdahalesini yalnızca iktisat teorisine göre gerekçelendirmek yetersiz olsa da çalışmanın kapsamı açısından bu şekilde bir sınırlandırma uygun olacaktır.

Kamusal mallarla ilişkili olan ve piyasa başarısızlığı olarak görülen diğer konu ise özellikle 2. Dünya Savaşı sonrası devletin ekonomiye müdahalesine gerekçe olarak en sık gösterilen “dışsallıklar"dır (Tanzi, 1997: 11). Kamusal malların üretim veya tüketimi, malın fiyatına yansıtılmayan dişsallıklar yaymaktadır ve devlet müdahalesi olmadan bu malların üretimi, yaydığı dışsallığın pozitif veya negatif olmasına göre optimum üretim seviyesinin altında veya üzerinde olması ile sonuçlanacaktır. Refah iktisatçılarına göre piyasanın Pareto etkinliği, kamusal mallar ve dışsallıkların varlığı durumunda, finansmana katılamayacak kişilerin tüketimden dışlanmasının oluşturduğu refah kaybından ve üretilip tüketilmeyen kısımdan dolayı bozulacaktır (Stiglitz, 2000: 89), bu durumda teşvik veya vergi yoluyla devlet müdahalesi gerekli olacaktır (Mikesell, 2007: 9; Pigou, 1952: 224).

Kamusallık niteliği yüksek olan mal ve hizmetlerin (koruyucu sağlık hizmetleri gibi) üretiminin özel sektöre bırakılması durumunda dışlanan kesim, bu mal ve hizmetlerin temel müşterisi konumundaki düşük gelirlilerdir. Bu hizmetlerin devlet tarafindan sunumu ise refah artırıcı "yeniden dağıtımı" sağlayabilecektir (Gupta vd., 2002: 718; Çevik, 2013: 115; Mikesell, 2007: 15; Tuncer ve Yüksel, 2011: 241-242).Dolayısıyla bu hizmetlerin özel sektöre tamamen bırakılamayacağ 1 ve sağlik sistemlerinin temel hedefi olan gelirden bağımsız olarak tüm vatandaşlar için "eşit erişimin", devlet müdahalesiyle sağlanacağ savunulur (Poterba, 1997; Self ve Grabowski, 2003: 1).

Coase (1960) gibi, piyasanın dışsallıkları içselleştirerek devlet müdahalesine gerek kalmadan "optimumu" sağlayacağ 1 düşüncesini savunanlar olsa da, görüldüğü gibi iktisat teorisi (normatif teoriler) devletin sağlığa müdahalesini çoğunlukla kamusal mallar ve dışsallıklar söz konusu olduğunda piyasa mekanizmasının, toplumun optimumunu sağlayamayacak olmasına, ortaya çıkacak etkinsizliğin devlet tarafından giderilmesi gerektiğine ve devletin "yeniden dağıtım" fonksiyonuna bağlamaktadır (Fuchs, 1998; Jack, 2000: 62; Poterba, 1997; Tanzi, 2009).

Devletin sağlıktaki rolünün, 20.yüzyllda dünya genelinde (ülkeler kendi iç dinamiklerine göre farklılık gösterse de) arttığı görülmektedir (Tanzi, 1997: 9). İkinci Dünya Savaşı sonrası sağlık hakkı uluslararası düzeyde kabul gören temel insan haklarından biri haline gelmiş ve küresel kamusal mal olarak kabul edilen sağlık hizmetleri önemli derecede kamulaştırılarak, sağlık riskleri kolektif riskler olarak tanımlanmıştır. Sağlık sigortası vatandaşlara devlet tarafindan sağlanmaya başlanmış ve devlet finansman- kaynak ve harcamalar açısından sağlık alanına geniş çaplı müdahil olmuştur (Fuchs, 1998; Altay, 2007: 33; Tanzi, 2009; Yılmaz ve Yentürk, 2015). Aynı dönemde sağlıktaki kamusallaşma tüm dünyada olduğu gibi Türkiye'de de gözlemlenmiştir. Ancak 1980 sonrasında bütçe açıklarının, kamu için sağlık hizmetlerinin finansmanını ağırlaştırması, küreselleşmenin piyasaya dayalı liberal yaklaşımları desteklemesi ve etkin hizmet sunumu gerekçeleri özelleştirmeleri hızlandırmış ve kamunun payının artması yönündeki görüşler yerini, kamu harcamalarının kısılması yönündeki görüşlere bırakmıştır (Altay, 2007: 33). Ancak günümüzde özellikle yüksek gelirli ülkelerde kamunun sağlıktaki payı özel sektörden fazladır. Salgın hastalıklara karşı aşılama gibi kamunun sunduğu koruyucu sağlı hizmetlerinin 19. ve 20. yüzyllda ölüm oranlarını düşürme gibi iyileştirici sonuçları yadsınamaz. Bugün ise kamu, sağlık sigortası ve bakım hizmeti dahil sağlığın genelini kapsayıcı şekilde bir pay edinmiştir. Hemen hemen hiçbir ülke özellikle koruyucu sağlık hizmetlerini piyasa şartlarına bırakamamaktadır. 


\section{Dünyada Kamu Sağlık Harcamalarının Ve Bazı Sağlık Sonuç Göstergelerinin Genel Görünümü}

Sağlık finansman sistemleri ülkeden ülkeye değişmektedir. Kimi ülkeler vergiye dayalı finansman sağlarken, kimi ülkelerde vatandaşların cepten yaptıkları harcamalar ve özel sigorta sistemleri önemli yer tutmaktadır (Fuchs, 1998). Az gelişmiş ülkelere uluslararası kuruluşlar, topluluklar ve diğer devletler tarafından yapılan yardımlar da finansman kaynağı olarak kabul edilebilir (Çevik, 2013: 116).

Dünya genelinde sağlık finansmanında kamunun payının arttığı 1950'ler sonrasında, ülkelerin kendi rakamlarında değişimler olduğu gibi, ülkeler arasında da kamunun sağlık içerisindeki payları farklılıklar göstermektedir. ABD'de, 1960 yılında sağlıkta kamu finansmanı \% 24 iken 2013 yılında her ne kadar OECD ülkeleri içerisinde en düşük değere sahip olsa da kamunun payı \% 47'ye çıkmıştır. İngiltere'de ise toplam sağlık harcamaları içerisinde kamunun payının hem 1960 yılında (\%85) hem 2013 yılında (\%83) yüksek olduğu görülmektedir. Almanya' da da, İngiltere'de olduğu gibi hem 1960 yılında (\%66) hem 2013 yılında (\%76) kamunun sağlık harcamaları içindeki oranı yüksektir. Ancak hem İngiltere hem Almanya'da kamu sağlık harcamaları 1980- 2010 yılları arasında eğitim, sağlık gibi alanlarda kamunun payının kısıldığı politikalardan dolayı, ortalama değerinden az da olsa düşüş göstermiştir (Berger ve Messer, 2002: 2105- 2106, WHO, 2015: 126- 134). 2010 sonrasında ise İngiltere'de sağllk reformu ile hem direkt hizmet sunumu hem de özel sektörün zararını finanse etme noktasında devletin rolü tekrar artmış, sağlık bakımı temel olarak vergi gelirlerinden finanse edilen İngiltere, ulusal sağllk hizmetleri modelinin en başarılı uygulayıcılarından biri haline gelmiştir (Kutzin, 2001: 172). Almanya sosyal sağlık sigortasının en önemli ve en başarılı temsilcisi iken, ABD ise özel sağlık finansman modelinin incelenebileceği en önemli örnektir (Günaydın, 2011: 346). 1995- 2013 yılları arasında sağlık harcamaları içerisinde kamunun payının yaklaşık \%60 olduğu OECD üyelerine bakıldığında ise, ortalamanın çok altında olan ABD (\%45), Meksika (\%46) ve Şili (\%39) dışındaki diğer ülkelerde kamu finansmanının ağırlıklı olduğu görülmektedir (http://www.worldbank.org). 2013 yılında Türkiye'de ise sağlık harcamalarında kamunun payının OECD ortalamasının bile çok üstünde (\%77) bir değer aldığı görülmektedir. Sağlık finansman modelleri ile ilgili İngiltere, Almanya ve A.B.D. örnek olarak detaylica incelenmesi gereken ülkelerdir. Ancak ülkelerin sağlık finansman yapıları veya sağlık politikaları bu çalışmanın kapsamını aşmaktadır, bu nedenle Dünya Sağlık Örgütü (WHO)'nün gruplandırması ve Dünya Bankası'nın gelir sınıflandırmasına göre sağlık harcamalarının kamu- özel ayrımı yapılarak genel seyrine yer vermek yeterli görülmüştür.

Çizelge 1' de Dünya Sağlık Örgütü (WHO)'nün ülkeleri altı bölgeye ayırarak yaptığ1 sınıflandırmaya göre 1995 ve 2013 yıllarında sağlık harcamalarının GSYİH'ye oranı, toplam sağlık harcamaları içerisinde kamu- özel ayrımı ve kişi başı sağlık harcamaları gibi finansman türlerine göre ayrılarak sunulmuştur.

Çizelge 1. Finansman Türüne Göre Sağlık Harcamaları, WHO Sınıflandırması (1995-2013)

\begin{tabular}{|c|c|c|c|c|c|c|c|c|}
\hline Bölge & Yll & TSH & $\begin{array}{l}\text { Kişi } \\
\text { başı } \\
\text { TSH } \\
\end{array}$ & KSH & $\begin{array}{l}\text { Kişi } \\
\text { başı } \\
\text { KSH } \\
\end{array}$ & KSH & ÖSH & $\begin{array}{l}\text { Cepten } \\
\text { harcam } \\
\text { a }\end{array}$ \\
\hline & & $\begin{array}{l}\% \\
\text { GSYIH }\end{array}$ & SGP \$ & \% ТКН & SGP \$ & \multicolumn{3}{|c|}{$\% \mathrm{TSH}$} \\
\hline Afrika & 1995 & 2.6 & 95 & 3.7 & 40 & 41.6 & 58.4 & 36.4 \\
\hline
\end{tabular}




\begin{tabular}{|c|c|c|c|c|c|c|c|c|}
\hline Ülkeleri & 2013 & 5.8 & 222 & 11.4 & 110 & 49.5 & 50.5 & 31.7 \\
\hline \multirow[t]{2}{*}{ Amerika } & 1995 & 10.9 & 1649 & 14.7 & 767 & 46.5 & 53.5 & 18.7 \\
\hline & 2013 & 13.6 & 3873 & 17.3 & 1904 & 49.2 & 50.8 & 15.7 \\
\hline \multirow{2}{*}{$\begin{array}{l}\text { Güney- } \\
\text { Doğu } \\
\text { Asya }\end{array}$} & 1995 & 3.4 & 69 & 5.5 & 22 & 32.0 & 68.0 & 59.3 \\
\hline & 2013 & 3.8 & 225 & 6.0 & 88 & 39.2 & 60.8 & 50.8 \\
\hline \multirow[t]{2}{*}{ Avrupa } & 1995 & 7.8 & 952 & 12.3 & 727 & 76.4 & 23.6 & 16.4 \\
\hline & 2013 & 9.3 & 2214 & 15.2 & 1667 & 75.3 & 24.4 & 19.5 \\
\hline \multirow{2}{*}{$\begin{array}{l}\text { Doğu } \\
\text { Akdeniz }\end{array}$} & 1995 & 3.7 & 198 & 5.8 & 94 & 47.4 & 52.6 & 46.7 \\
\hline & 2013 & 4.5 & 576 & 7.3 & 284 & 49.4 & 50.6 & 43.6 \\
\hline \multirow{2}{*}{$\begin{array}{l}\text { Batı } \\
\text { Pasifik }\end{array}$} & 1995 & 5.2 & 216 & 13.8 & 148 & 68.6 & 31.4 & 25.9 \\
\hline & 2013 & 6.6 & 925 & 14.4 & 582 & 62.9 & 37.1 & 28.6 \\
\hline \multirow[t]{2}{*}{ Dünya } & 1995 & 7.4 & 472 & 12.2 & 273 & 57.9 & 42.1 & 21.7 \\
\hline & 2013 & 8.7 & 1187 & 14.3 & 685 & 57.7 & 42.2 & 22.4 \\
\hline
\end{tabular}

Kaynak: Dünya Sağl1k Örgütü (WHO), Global Health Observatory Data Repository

TSH: Toplam Sağlık Harcaması, KSH: Kamu Sağlık Harcaması, ÖSH: Özel Sağlık Harcaması, TKH: Toplam Kamu Harcamaları, SGP: Satın Alma Gücü Paritesi

Çizelge 1'e bakıldığında sağlık harcamalarının GSYİH içindeki payı Afrika ülkeleri için 1995 yılından $(\% 2,6)$, 2013'e $(\% 5,8)$ kadar artı̧̧ göstermiş olsa da yine de dünya ortalamasının altında kalmaktadır. Toplam sağlık harcamalarının GSYİH içindeki payının en yüksek olduğu bölge ise hem 1995 (\%10.9) hem 2013 (\%13.6) yıllarında Amerika'dır. Ancak Amerika'nın sahip olduğu bu yüksek değer, toplam sağlık harcamaları içerisinde kamunun payı söz konusu olduğunda dünya ortalamasının altında kalmaktadır. Çünkü Şekil 1'e bakıldığında hem 1995 yılında (\%46.5) hem 2013 yılında (\%49.2) Amerika'nın Afrika, Güney Doğu Asya ve Doğu Akdeniz bölgeleriyle birlikte sağlikta kamunun payının en düşük olduğu bölgelerden biri olduğu görülmektedir. Toplam sağlık harcamaları içerisinde kamunun payının 1995 yılından 2013 yılına kadar -dünya ortalamasından yüksek olsa daAvrupa ve Batı Pasifik bölgelerinde düştüğü, her iki yılda da dünya ortalamasının altında olan Afrika, Güney Doğu Asya, Doğu Akdeniz ve Amerika'da ise yükseldiği görülmektedir. Toplam sağlık harcamaları içerisinde kamunun payının hem 1995 hem 2013 yılında dünya ortalamasının da üstünde olarak en yüksek değere Avrupa ülkelerinin sahip olduğu görülmektedir. 


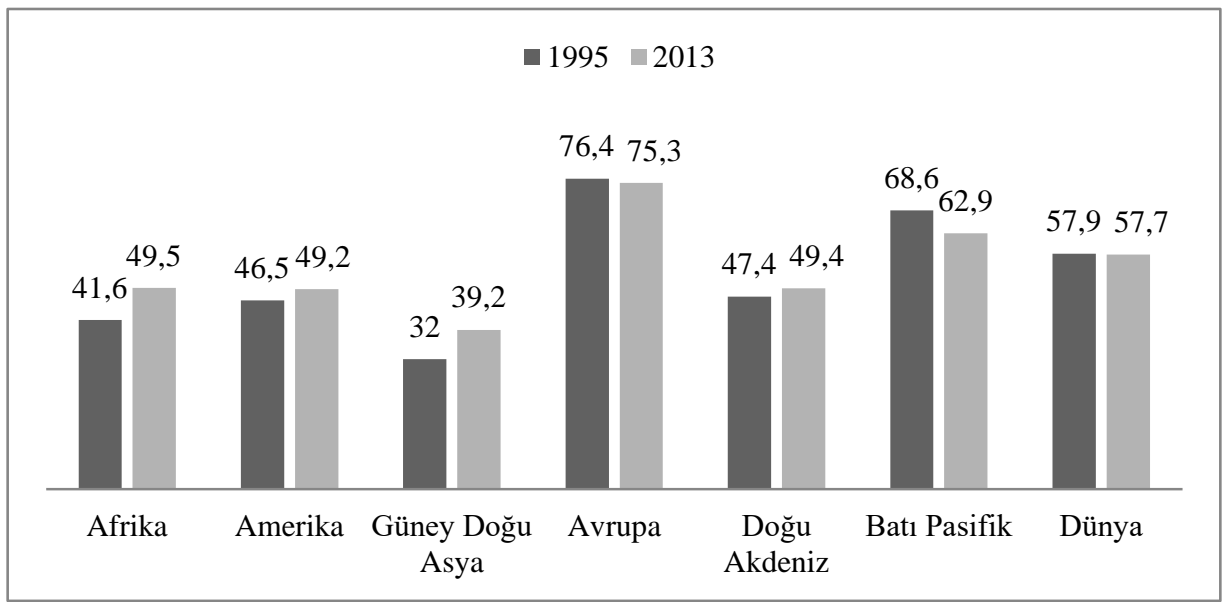

Kaynak: Dünya Sağlık Örgütü (WHO), Global Health Observatory Data Repository

Şekil 1'den görüldüğü gibi toplam sağlık harcamaları içinde kamu sektörünün payı Avrupa ve Batı Pasifik dışındaki diğer bölgelerde 2013 yılında 1995 yılına göre artış göstermiştir.

Aşağıda Çizelge 2'ye bakıldığında ise bölge olarak Afrika, bebek ve çocuk ölüm oranlarında her ne kadar 1995 yılından $(102.8,170.2) 2013$ yılına $(58.5,87,3)$ kadar gerileme kaydetse de yine de her iki yılda da iki gösterge için en yüksek değere sahip bölgedir. 1995 yılında Avrupa en düşük bebek (22.7) ve çocuk ölüm (27.9) oranlarına sahip iken, 2013 yılında da her iki gösterge için en düşük değere sahiptir.

Çizelge 2. Seçilmiş Bazı Sağlık Sonuç Göstergeleri, WHO sınıflandırması, (1995-2013)

\begin{tabular}{|l|l|l|l|}
\hline \multirow{3}{*}{ Afrika } & & $\begin{array}{l}\text { Bebek ölüm oranı (1000 sağ } \\
\text { doğumda) }\end{array}$ & $\begin{array}{l}\text { 5 yaş altı çocuk ölüm oranı } \\
\text { (1000 çocukta) }\end{array}$ \\
\hline \multirow{2}{*}{ Amerika } & $\mathbf{2 0 1 3}$ & 58.5 & 87.3 \\
\cline { 2 - 4 } & $\mathbf{1 9 9 5}$ & 102.8 & 170.2 \\
\cline { 2 - 4 } & $\mathbf{2 0 1 3}$ & 13.1 & 15.4 \\
\hline \multirow{2}{*}{$\begin{array}{l}\text { Güney Doğu } \\
\text { Asya }\end{array}$} & $\mathbf{2 0 1 3}$ & 36.7 & 33.4 \\
\cline { 2 - 4 } & $\mathbf{1 9 9 5}$ & 72.2 & 46.4 \\
\hline \multirow{3}{*}{ Avrupa } & $\mathbf{2 0 1 3}$ & 10.5 & 100.6 \\
\cline { 2 - 4 } & $\mathbf{1 9 9 5}$ & 22.7 & 12.1 \\
\hline \multirow{2}{*}{$\begin{array}{l}\text { Doğu } \\
\text { Akdeniz }\end{array}$} & $\mathbf{2 0 1 3}$ & 42.9 & 27.9 \\
\cline { 2 - 4 } & $\mathbf{1 9 9 5}$ & 67.3 & 55.5 \\
\hline \multirow{2}{*}{ Batı Pasifik } & $\mathbf{2 0 1 3}$ & 12.6 & 90.1 \\
\cline { 2 - 4 } & $\mathbf{1 9 9 5}$ & 34.2 & 15.1 \\
\hline \multirow{2}{*}{ Dünya } & $\mathbf{2 0 1 3}$ & 33.7 & 44.0 \\
\cline { 2 - 4 } & $\mathbf{1 9 9 5}$ & 60.0 & 45.6 \\
\hline
\end{tabular}

Kaynak: Dünya Sağllk Örgütü (WHO), Global Health Observatory Data Repository 
Çizelge 1 ve Çizelge 2 aynı anda dikkate alındığında, sağlık harcamalarının GSYİH içindeki payının en yüksek olduğu ülke olan Amerika'da bebek ve çocuk ölümlerinin, sağl1k harcamalarının GSYİH içindeki payının daha düşük olduğu Avrupa'dan yüksek olduğu görülmektedir. Diğer faktörleri dikkate almadan yapılacak bir çıkarım eksik olsa da, Avrupa ülkelerinin sağlık harcamalarının (\%GSYİH) Amerika'ya göre daha etkili olduğu söylenebilir.

Sağlık harcamalarında kamunun payı dikkate alınacak olursa, kamu sağlık harcamalarının ve çocuk ölüm oranlarının 2013 yılındaki değerlerini aynı grafik üzerinde toplayan aşağıdaki Şekil 2'ye göre, sağlik harcamalarında kamunun payının en yüksek olduğu Avrupa ülkelerinin, bebek ve çocuk ölüm oranları gibi sağlık göstergelerinde en düşük değere sahip olduğu görülmektedir. Ancak bu birliktelik, elbette Avrupa'da bebek ve çocuk ölüm oranlarının düşük olmasını diğer faktörlerin dışlanarak yalnızca sağlık harcamalarında kamunun payının yüksek olmasına bağlamak için yetersizdir.

Şekil 2. Kamu Sağlık Harcamaları (\% Toplam Sağlık Harcamaları) ve Çocuk Ölüm Oranları (2013)

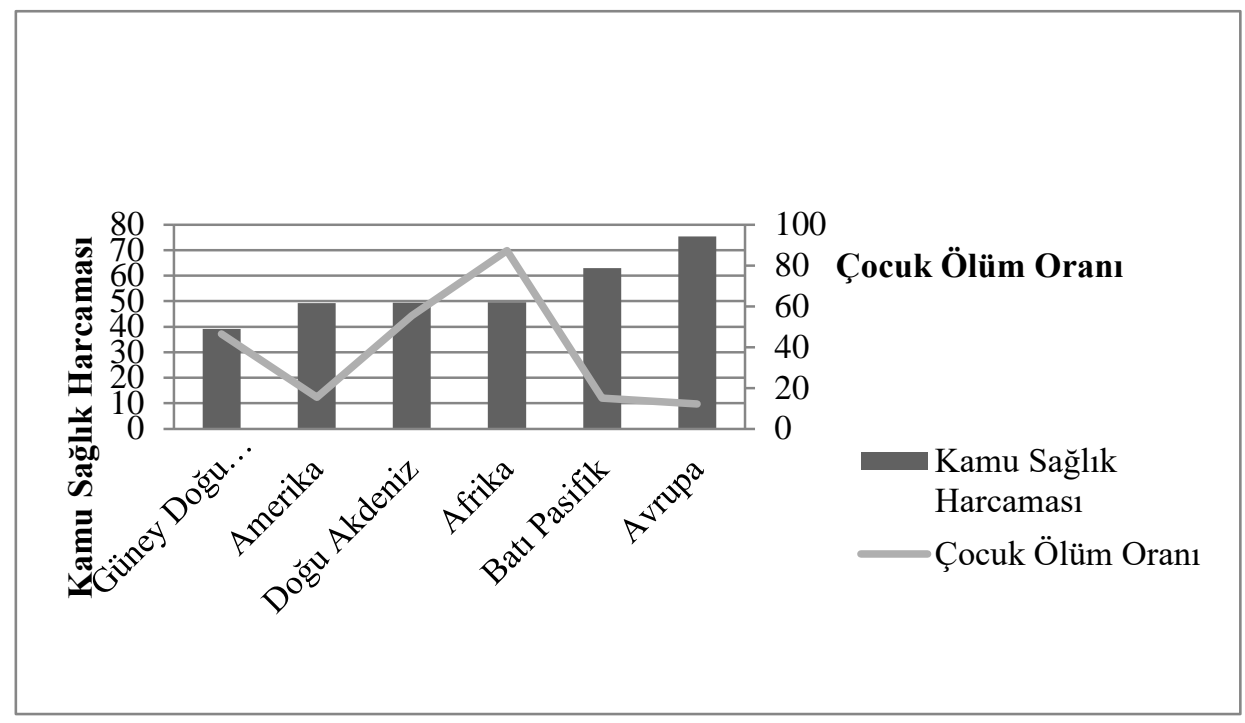

Kaynak: Dünya Sağlık Örgütü (WHO), Global Health Observatory Data Repository

Şekil 3 ise, Dünya Bankası'nın sınıflandırmasına göre, dört gelir grubu için 2013 yılında kamu finansman paylarını göstermektedir. 2013 yılı için yüksek ve yüksek- orta gelirli ülkelerde toplam sağlık harcamaları içerisinde kamunun payının sırasıyla $(\% 60)$ ve $(\% 56)$ ile yaklaşık olarak dünya ortalaması seviyesindeyken (\%57), düşük ve düşük- orta gelirli ülkelerde bu değerlerin sırasıyla (\%39) ve (\%37) ile dünya ortalamasının çok altında olduğu görülmektedir. 
Şekil 3. Dünya Bankası'nın Gelir Seviyelerine Göre Gruplandırmasında Toplam Sağlık Harcamaları İçinde Kamunun Payı (\%) (1995- 2013)

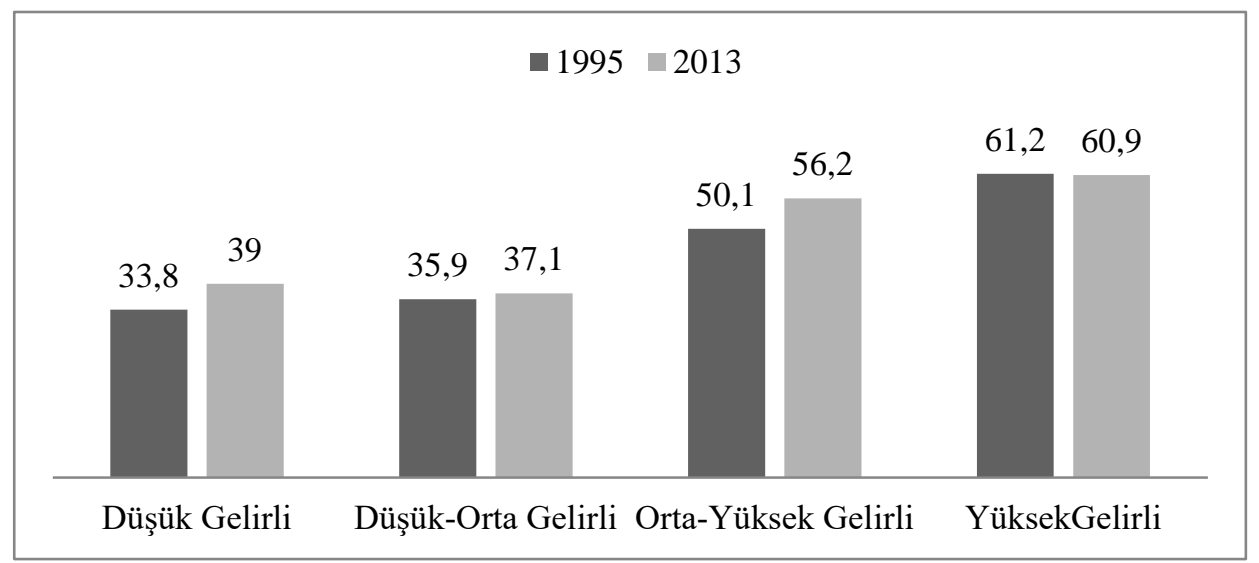

Kaynak: Dünya Sağllk Örgütü (WHO), Global Health Observatory Data Repository

Dünya Bankası sınıflandırmasına göre, ülke gruplarının 1995 ve 2013 yıllarında bebek ve çocuk ölüm oranlarını gösteren Çizelge 3'e bakıldığında, her ne kadar 1995 yılından 2013 yılına kadar gerileme görülse de, düşük gelirli ülkelerin her iki yılda da en yüksek ölüm oranlarına sahip oldukları görülmektedir. Her iki yılda da en düşük bebek ve çocuk ölüm oranına sahip ülke grubunun ise yüksek gelirliler olduğu görülmektedir.

Çizelge 3. Seçilmiş Bazı Sağlık Sonuç Göstergeleri (Dünya Bankası Sınıflandırması (1995-2013)

\begin{tabular}{|c|c|c|c|}
\hline & & $\begin{array}{l}\text { Bebek ölüm oranı (1000 } \\
\text { sağ doğumda) }\end{array}$ & $\begin{array}{l}5 \text { yaş altı çocuk ölüm oranı } \\
\text { (1000 sağ doğumda) }\end{array}$ \\
\hline \multirow[b]{2}{*}{ Düşük Gelirli Ülkeler } & 2013 & 56.3 & 81.9 \\
\hline & 1995 & 104.4 & 172.1 \\
\hline \multirow{2}{*}{$\begin{array}{l}\text { Düşük-Orta } \\
\text { Ülkeler } \\
\end{array}$} & 2013 & 42.7 & 56.8 \\
\hline & 1995 & 74.5 & 106.3 \\
\hline \multirow{2}{*}{$\begin{array}{l}\text { Yüksek-Orta Gelirli } \\
\text { Ülkeler }\end{array}$} & 2013 & 16.4 & 20.7 \\
\hline & 1995 & 38.1 & 48.3 \\
\hline \multirow{2}{*}{$\begin{array}{l}\text { Yüksek } \\
\text { Ülkeler }\end{array}$} & 2013 & 6.1 & 7.2 \\
\hline & 1995 & 10.1 & 12.2 \\
\hline \multirow[b]{2}{*}{ Dünya } & 2013 & 33.7 & 45.6 \\
\hline & 1995 & 60.0 & 85.3 \\
\hline
\end{tabular}

Kaynak: Dünya Sağlık Örgütü (WHO), Global Health Observatory Data Repository 
Şekil 4 ise, çocuk ölüm oranının, ülkelerin gelir seviyeleri arttıkça düştüğünü göstermektedir.

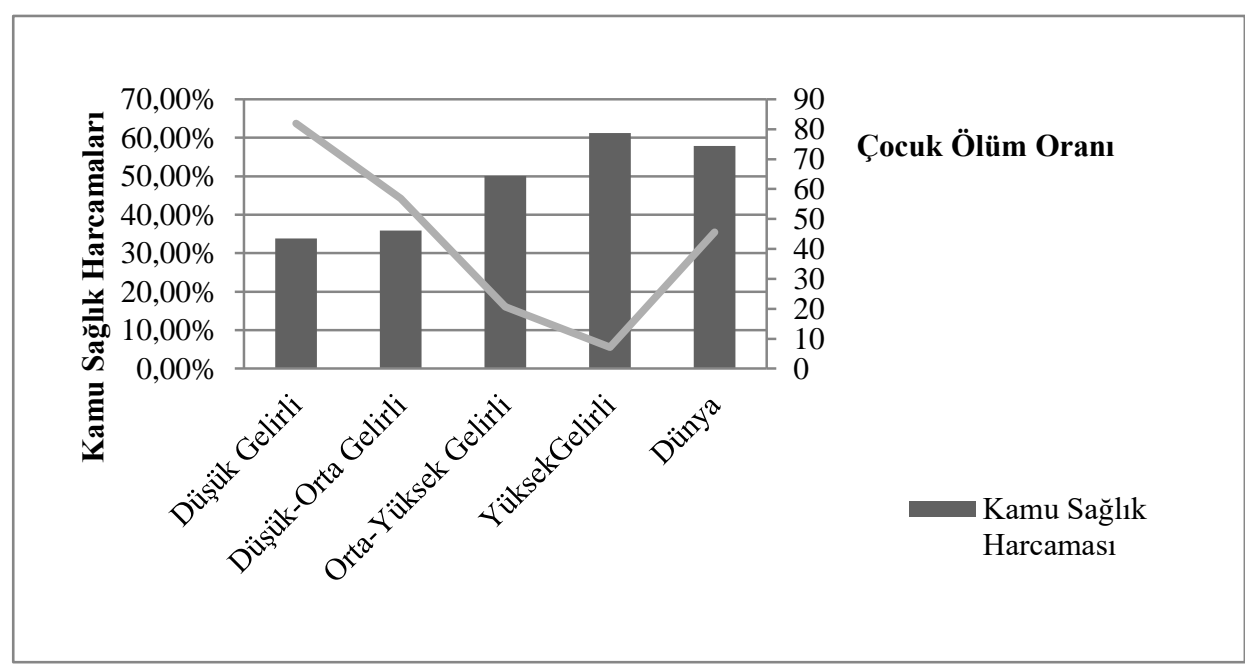

Kaynak: Dünya Sağllk Örgütü (WHO), Global Health Observatory Data Repository

Şekil 4. Kamu Sağlık Harcamaları (\% Toplam Sağlık Harcamaları) ve Çocuk Ölüm Oranları (2013)

\section{Kamu Sağlık Harcamaları Ve Sağlık Sonuç Göstergeleri: Literatür Özeti}

Süreç içerisinde geçirdiği değişimlere rağmen kamunun sağliktaki doğrudan ve dolaylı rolü azımsanamaz. Bu noktada önemli olan sorulardan birisi de "kamu sağlık harcamalarının, sağlık sonuç göstergelerini iyileştirip, iyileştirmediğidir". Bazı durumlarda kamu sağlık harcamaları sağlık bakım hizmetlerine erişimi artırarak sağlık sonuçlarını iyileştirirken bazı durumlarda da kamu finansmanı sağlık bakım hizmetlerinin sunumunda etkinsizlik ortaya çıkararak sağlık sonuçlarını olumsuz etkileyebilmektedir (Berger ve Messer, 2002: 21052106).

Sağlık sonuç göstergelerini iyileştirmede, bir girdi olarak kamu sağlık harcamalarının etkisini ifade eden "kamu sağlık harcamalarının etkililiği", hem ülkelerin gelir seviyelerine hem de ülke içindeki gelir gruplarına göre farklılaşabilmektedir. Çok çeşitli boyutlarının olması nedeniyle "kamu sağlı harcamalarının etkililiği", ampirik olarak incelenmesi gereken bir konudur. Bu konuyla ilgili daha önce yapılmış ampirik çalışmalar ve bulgularına ilişkin literatür özeti aşağıdaki çizelgede yer almaktadır.

Çizelge 4. Literatür Özeti

\begin{tabular}{|c|c|}
\hline Çalışma & Bulgu \\
\hline $\begin{array}{l}\text { Anand } \\
\text { \& } \\
\text { Ravallion } \\
\text { (1993) }\end{array}$ & $\begin{array}{l}1985 \text { yılı verileriyle } 22 \text { ülke için yaptıkları çalışmada, iktisadi büyümenin satın alma } \\
\text { gücünü artırarak, yoksulluğu azaltarak ve kamu hizmetlerini artırarak sağlık sonuçlarını } \\
\text { (bebek ve çocuk ölüm oranları, doğumda beklenen yaşam süresi) iyileştirici etkisi olduğunu } \\
\text { ileri sürmüşlerdir. }\end{array}$ \\
\hline $\begin{array}{l}\text { Bidani } \quad \& \\
\text { Ravallion } \\
\text { (1997) }\end{array}$ & $\begin{array}{l}\text { Otuzbeş gelişmekte olan ülke için yaptıkları çalışmada sağlık sonuç göstergelerini nüfusun } \\
\text { yüksek ve düşük gelirli grupları arasında ayrıştırmışlardır. Rassal etkiler modeli sonucu } \\
\text { kamu sağlık harcamalarının düşük gelirliler için beklenen yaşam süresi ve bebek ölüm oranı } \\
\text { üzerinde daha etkili olduğunu bulmuşlardır. }\end{array}$ \\
\hline
\end{tabular}




\begin{tabular}{|c|c|}
\hline$\underset{(1999)}{\&} \quad$ Pritchett & $\begin{array}{l}\text { Filmer ve Pritchett (1999), daha önce yapılmış çalışmalarda gelir eşitsizliği ve başka } \\
\text { dışlanmış değişkenleri de dahil ederek gelişmekte olan yüz civarında ülke için yürüttükleri } \\
\text { yatay kesit regresyonlarda koruyucu sağlık hizmetlerine yapılan kamu harcamalarının, } \\
\text { sağlık sonuç göstergeleri olarak seçilen bebek ve çocuk ölüm oranları üzerinde istatistiksel } \\
\text { olarak anlamlı bir etkisini bulamamışlardır. Başta gelir eşitsizliği olmak üzere } \\
\text { sosyoekonomik ve demografik değişkenlerin daha etkili belirleyiciler olduğunu tespit } \\
\text { etmişlerdir. Böylece literatüre, hem dışlanmış değişkenleri dahil ederek hem de kamu sağlık } \\
\text { harcamaları ile sağlık sonuçları arasında oluşabilecek ters nedensellik ilişkisini göz önünde } \\
\text { bulundurarak araç değişken kullanımı yönünde katkı sağlamışlardır. }\end{array}$ \\
\hline $\begin{array}{l}\text { Gupta, } \\
\text { Verhoeven \& } \\
\text { Tiongson (1999) }\end{array}$ & $\begin{array}{l}\text { Elli gelişmekte olan ülke ve geçiş ekonomileri için yaptıkları yatay kesit regresyonlara } \\
\text { dayalı çalışmada kamu harcamalarının sağlık sektörüne kaydırılmasının bebek ve çocuk } \\
\text { ölüm oranlarını düşürdüğünü bulmuşlardır. Kamu sağllk harcamaları içerisinde ise } \\
\text { koruyucu sağlık hizmetlerine ağırlık verilmesinin daha da etkili olduğunu tespit etmişlerdir. }\end{array}$ \\
\hline $\begin{array}{l}\text { Gupta, } \\
\text { Verhoeven \& } \\
\text { Tiongson (2002) }\end{array}$ & $\begin{array}{l}40 \text { gelişmekte olan ülkenin 1985- } 1997 \text { yılları arası ortalaması ile yaptıkları, bebek ve çocuk } \\
\text { ölüm oranlarını sağlı sonuç göstergesi olarak kullandıkları çalışmalarında, kamu sağlık } \\
\text { harcamalarının bebek ve çocuk ölüm oranlarını düşürmede az da olsa etkili olduğu } \\
\text { sonucuna ulaşmışlardır. Yolsuzluğun ise kamu sağlık harcamalarının etkililiğini azalttığını } \\
\text { söylemişlerdir. }\end{array}$ \\
\hline $\begin{array}{l}\text { Berger \& } \\
\text { Messer (2002) }\end{array}$ & $\begin{array}{l}20 \text { OECD ülkesinin 1960-1992 yıllarına ait verilerini kullanarak yaptıkları çalışmada, } \\
\text { sağlık harcamalarında kamu finansmanını artırmanın, hizmet sunumundaki etkinsizlik } \\
\text { nedeniyle ölüm oranlarında artışa yol açtığını, sigorta sisteminin kapsayıcılığını artırmanın } \\
\text { ise ölüm oranlarını düşürdüğünü bulmuşlardır. }\end{array}$ \\
\hline $\begin{array}{l}\text { Self } \\
\text { Grabowski } \\
(2003)\end{array}$ & $\begin{array}{l}\text { Ülkeleri gelirlerine göre sınıflandırarak yatay kesit veri ile yaptıkları çalışmada gelişmiş } \\
\text { ülkelerde kamu sağlık harcamalarını sağlık sonuç göstergesi olarak seçilen DALE } \\
\text { (sakatlık düzeltilmiş hayat beklentisi) üzerinde anlamlı bir etkisi olmadığını, ancak } \\
\text { gelişmekte olan ve azgelişmiş ülkelerde kamu sağlık harcamalarının etkili olduğu sonucunu } \\
\text { bulmuşlardır. }\end{array}$ \\
\hline $\begin{array}{l}\text { Rajkumar } \\
\text { Sawaroop } \\
(2008)\end{array}$ & $\begin{array}{l}91 \text { ülkenin 1990, } 1997 \text { ve } 2003 \text { yıllarına ait verileri ile yönetişim indekslerini kamu sağlık } \\
\text { harcamaları ile "interaktif terim (interactive term)" olarak kullandıkları çalışmalarında } \\
\text { kamu sağlık harcamalarını artırmanın, ancak düşük yolsuzluk ve yüksek bürokratik kaliteye } \\
\text { sahip ülkelerde bebek ve çocuk ölüm oranlarını iyileştirici etkisi olduğunu, bu ülkelerde } \\
\text { kamu sağlık harcamalarının \%1'lik artışının beş yaş altı çocuk ölüm oranını \%0.32 } \\
\text { oranında düşürdüğünü bulmuşlardır. Yüksek yolsuzluk oranına sahip ve kamu yönetişimi } \\
\text { zayıf ülkelerde ise anlamlı bir etkisinin olmadı̆g sonucunu bulmuşlardır. }\end{array}$ \\
\hline $\begin{array}{l}\text { Mendoza } \quad \& \\
\text { Rees (2009) }\end{array}$ & $\begin{array}{l}\text { ndoza \& Rees (2009) bebek ve çocuk ölü } \\
\text { tikleri çalışmalarında birçok değişkenin }\end{array}$ \\
\hline Çe & $\begin{array}{l}\text { Verisine ulaşılabilir dünya ülkelerine ilişkin yatay kesit veri ile yapılan analizler hem } \\
\text { toplam sağlı harcamaları içinde hem de GSYİH içinde kamu sağlık harcamalarının çocuk } \\
\text { ölüm oranları üzerinde etkisi olduğu tespit edilmiştir. Ülkelerin gelir seviyelerine göre } \\
\text { kamu sağlık harcamalarının etkililiğinin farklı olacağı hipotezinden yola çıkarak Dünya } \\
\text { Bankası'nın gelir sınıflandırmasına göre gruplar için ayrı regresyonlar yürütülmüş ve } \\
\text { yüksek gelirli ülkelerde kamu sağlı harcamalarını çocuk ölüm oranlarını iyileştirici } \\
\text { etkisine dair karma bulgulara karşın düşük gelirli ülkelerde kamu sağlık harcamalarının } \\
\text { çocuk ölüm oranlarını düşürmede etkili olduğu bulunmuştur. }\end{array}$ \\
\hline $\begin{array}{l}\text { Hu \& Men } \\
\text { (2013) }\end{array}$ & $\begin{array}{l}136 \text { ülkenin 1960-2005 yıllarına ait veri seti kullanılarak, cari dönemin kamu sağlık } \\
\text { harcamasının bir sonraki yılın çocuk ölüm oranını etkileyeceği varsayımıyla, kamu sağl1k } \\
\text { harcamasının } 1 \text { dönem gecikmeli değerinin kullanıldığ analizde, hem kamu sağlık } \\
\text { harcamasının hem de yönetişim değişkenlerinin tüm modellerde olmasa da çocuk ölüm } \\
\text { oranı üzerinde etkili olduğu sonucuna ulaşmışlardır. }\end{array}$ \\
\hline
\end{tabular}

Literatüre bakıldığında kamu sağlık harcamalarının etkililiğine yönelik çelişen sonuçların yer aldığı görülmektedir. Kamu sağlık harcamalarının sağlık sonuçları üzerinde anlamlı ve pozitif etkisinin olduğunu bulan çalışmaların yanında, kamu sağlık harcamalarının yalnızca 
bazı ülke gruplarında etkili olduğunu bulanlar ve kamu sağlık harcamalarının etkisini görece küçük veya istatistiksel olarak anlamsız bulan çalışmalar yer almaktadır. Ancak kamu sağlık harcamalarını etkili bulan çalışmalar da dahil, hemen hemen bütün çalışmaların mutabık olduğu ve bu çalışmanın ekonometrik analiz kısmında da tespit edilen nokta ise, kamu sağlık harcamalarının sağlık sonuç göstergeleri üzerinde, diğer sosyoekonomik ve çevresel sağlığa yönelik değişkenlere göre daha az etkiye sahip olduğudur.

\section{Kamu Sağlık Harcamalarının Etkililiğine Yönelik Ampirik Analiz}

Referans alınan yukarıdaki çalışmaların, zaman içindeki değişimleri dahil etmeyen yatay kesit veri ile veya daha dar bir örnekleme dayanan panel veri ile çalıştıkları görülmektedir. Bulguların, örneklem yapısı, zaman aralığı ve kullanılan değişkenlere göre farklılık göstermesi, böyle bir çalışma için, geniş örnekleme dayanan ve gözlem sayısı yüksek analizlere ihtiyaç olduğunu göstermektedir. Bu nedenle bu çalıșmada on bir y1llık bir zaman aralığ1 ve görece daha geniş bir örneklem kullanılmıştır. Ayrıca birçok çalışmada kamu sağlık harcamalarının etkisi diğer sosyoekonomik ve çevresel faktörlerle karşılaştırılarak yorumlanmış, kamu sağlık harcamalarının etkililiğinde ülkelerarası farklar, ülkelerin gelir seviyeleri ile açıklanmıştır. Bu çalışmada ise kamu sağlık harcamalarının sağlık sonuç göstergelerini iyileştirmedeki etkisi, diğer değişkenlerle karşılaştırılmakla birlikte, ülkeler arası farkların gerekçelerinden biri olarak ülkelerin kurumsal yapısı ele alınmış ve bu hipotezi test etmek üzere Rajkumar ve Swaroop (2008)'un izlediği yöntem takip edilmiştir. Bu yöntemde yönetişim indeksi ile kamu sağlık harcamaları "interaktif terim" olarak analize dahil edilmiştir.

\subsection{Veri ve Değişken Seçimi}

Sağlık sonuç göstergeleri, bireylerin sağlıkla ilgili davranışlarını yönlendirecek bireysel kapasitelerinin (eğitim seviyesi), ülkelerin ekonomik göstergelerinin (kişi başı gelir, gelir dağılımı ve harcama seviyeleri), çevre sağlığının (hastalıkların yaygınlığı, temiz suya erişim ve hava kirliliği), ülkenin kurumsal kapasitesinin (yönetişim), altyapı göstergelerinin, demografik yapılarının ve bölgeye özgü şartlarının bir fonksiyonu olarak tahmin edilecektir (Cutler, 1996: 5-6; Çevik, 2013). Sağlık sisteminin girdi ve sonuçları arasındaki ilişkiyi temsil etmek üzere "toplam sağlik üretim fonksiyonu" olarak da ifade edilen fonksiyon aşağıdaki gibidir:

$S A \breve{G} L I K_{i}=\mathrm{f}($ Ekonomik Göstergeler, Eğitim Seviyesi, Sağllk Hizmetlerine Erişim ve Çevre Sağllğgl, Demografik Yapı, Kurumsal Kapasite, Bölgeye Ö̈zgü Şartlar)

Sağllk Sonuç Göstergesi Olarak 5 Yaş Altı Çocuk Ölüm Oranı: Sağlık sonuçlarının, birçok girdinin fonksiyonu olarak tahmin edildiği bir çalışmada ülkelerarası veriyle çalışmanın bazı dezavantajları vardır. Bir ülke nüfusunun sağlık durumunu ölçmek ve ülkelerarası kapsayıcı ve ölçülebilir bir sağlık sonuç göstergesi tespit etmek karmaşık ve zordur ${ }^{3}$ (Afonso ve Aubyn, 2005: 238). Genel olarak literatürde kullanılan sağlık sonuçları sübjektif (bireylere yapılan anket, vb. ile bireylerin sağlık durumlarıyla ilgili algılarını yansıtan algılanan sağlık durumu) ve objektif (sağlık durumunun yaklaşık bir değerini yansıtabilecek olan çocuk ölüm oranı, doğumda yaşam beklentisi gibi gözlemlenebilir sağlık durumu) değişkenler olarak

\footnotetext{
${ }^{3}$ Tek bir ülke için hanehalklarına yapılan anketler aracılığıyla toplanan mikro veriyle, hem bireylerin sağlık durumuna yönelik bilgi edinilebilir hem de sağlık sistemi sabit tutularak yalnızca fonksiyondaki girdilerin marjinal ürünlerini tahmin etmeye odaklanılabilir. Ancak sağlık sistemlerinin yapısıyla ilgili (kamu - özel finansman payları gibi) değişikliklerin veya farklılıkların sağlık sonuçlarına etkisi tahmin edilmek istendiğinde, sağlık sisteminin genellikle kısa zaman diliminde varyasyon göstermeyecek olması tek bir ülkede sağlık sisteminin etkisini görmeyi engelleyecektir dolayısıyla geniş bir örneklem seçmek gerekmektedir (Berger ve Messer, 2002: 2106).
} 
ayrılmaktadır (Çevik, 2013: 118). Yatay kesit veya panel veri ile yapılan çalışmaların büyük kısmı ölçülebilir ve ülkelerarası mukayeseye imkan tanıyan genel kabul görmüş objektif sonuç göstergeleri (tüm nüfus veya cinsiyete göre ölüm oranları, doğumda yaşam beklentisi, sakatlık düzeltilmiş yaşam beklentisi gibi) kullanmışlardır. Analiz sonuçlarının diğer çalışmalarla karşılaştırılabilmesi için Filmer ve Pritchett (1999), Gupta vd. (2002), Rajkumar ve Swaroop (2008), Hu ve Mendoza (2013), Çevik (2013) gibi çalı̧̧malar takip edilerek, Birleşmiş Milletler ve birçok uluslararası kuruluşun kalkınma hedeflerinde de temel sağlık göstergelerinden olan ve sağlık sonuçları için iyi birer yaklaşık değer olarak görülen beş yaş altı çocuk ölüm oranı ${ }^{4}$ kullanılmıştır. Böylelikle daha önce yapılmış çalışmaların sonuçlarıyla karşılaştırma yapılabilmesi sağlanacaktır.

Yukarıdaki sağlık fonksiyonundan yola çıkılarak kullanılacak olan bağımsız değişkenler:

Gelir: Literatüre bakıldığında Filmer ve Pritchett (1999), Gupta vd. (2002), Rajkumar ve Swaroop (2008), Hu ve Mendoza (2013) gibi çalışmalarda diğer değişkenler sabitken gelirin sağlık durumu üzerindeki etkisinin pozitif olduğu görülmektedir. Gelirin sağlık sonuçları üzerindeki etkisi birçok dolaylı ve doğrudan kanaldan gerçekleşebilmektedir (Filmer ve Pritchett, 1999: 1310). Aradaki doğrudan ilişki ilk olarak ülkenin ekonomik gelişmişlik göstergelerinden biri olan yüksek kişi başı gelire sahip olmasının vatandaşlara sağlanan sağlık imkanlarını artırmasıdır. İkincisi ise kişi başı gelirin yüksek olması, bireyin kendisi ve çocuklarının güvenli gıda, temiz su ve sağlık hizmetlerine ulaşmalarını kolaylaştırmasıdır (Hu ve Mendoza, 2013). Ülkenin ekonomik performansını ve bireylerin sağlık talebini etkileyecek olan gelirin yaklaşık bir değeri olarak en çok kullanılan değişken kişi başı gayrisafi yurtiçi hasıla olmaktadır.

Gelir Eşitsizliği: Wilkinson (1992), Berger ve Messer (2002) gibi çalışmalar gelir eşitsizliğinin sağlık sonuçlarını kötüleştirdiğini savunmuşlardır. Gelir eşitsizliğinin ülkeler arası karşılaştırması için gini katsayısı kullanılacaktır.

Eğitim: Bireyler özelinde sağlık sonuç göstergeleri hane halklarının sağlık hizmetlerine erişimlerinden etkileneceği gibi, yaşam tarzlarıyla ilgili olan doğru beslenme, spor alışkanlığı, günlük alkol ve sigara tüketimi gibi sağlığı doğrudan etkileyici davranışsal faktörlerden de etkilenir (Feinstein, 1993: 280; Cutler, Deaton ve Lleras- Muney, 2006: 113). Eğitimin, bireylerin bilgi ve bilişsel yeteneklerini artırıp yaşam tarzlarını çevre ve sağlık gibi konularda daha duyarlı olma yönünde değiştirmesinden dolayı sağlı üzerindeki etkisi yadsınamaz (Feinstein, 1993). Bu ilişkiye yönelik öncül çalışmalardan biri olan Grossman (1972), eğitim ile sağlık arasındaki ilişkiyi davranışlardan başka bir de gelir kanalı üzerinden kurmaktadır. Eğitim daha yüksek ücretle istihdam edilebilmeyi sağlar ve bu sayede bireylerin sağlık hizmetlerine erişim imkanlarını artırır ve sağlıklarına gelirleri oranında yatırım yapmalarını yani sağlık stoklarını artırmalarını sağlar (Grossman, 1972). Hem makro hem de hane halkı düzeyinde yapılan çalışmalara göre kadın okuryazarlık oranı daha iyi sağlık durumuyla sonuçlanmaktadır (Filmer ve Pritchett, 1999: 1311). Hu ve Mendoza (2013) kadınların eğitim seviyesinde küçük bir artışın bile çocuk sağlığı üzerinde etki ettiğini ileri sürmüştür. Dolayısıyla da sağlığa yönelik bireysel ve toplumsal kapasiteyi yansıtması açısından (Çevik, 2013) ülkelerin kadın nüfus için beklenen okullaşma oranı (ilkokul ve ortaokul) bağımsız değişken olarak regresyona dahil edilmiştir.

\footnotetext{
${ }^{4}$ Çocuk ölüm oranları, herhangi bir olağanüstü olay (savaş, doğal afet vb.) olmadığı sürece yıllık olarak ciddi değișiklikler göstermez, uzun vadeli ve dișsal faktörlerden etkilenen bir politika sonucudur, dolayısıyla kısa vadede önemli bir dalgalanma göstermemesi nedeniyle çocuk ölüm oranının bağımlı değişken olduğu bir çalışmada panel veri ya da yatay kesit veri kullanılması uygun olmaktadır.
} 
Kamu Sağlık Harcamalarl: $\mathrm{Bu}$ çalışma ile araştırılmak istenen kamu sağlıkharcamalarının sağlık sonuçları üzerindeki etkisidir. Literatürde bu etkiye yönelik bulunan karmaşık sonuçlar literatür özeti kısmında anlatılmıştı. Dolayısıyla da kamunun sağlık politikalarını yansıtması açısından sağlık harcamalarının GSYIH'ye oranı kullanilacaktır.

Kırsal Nüfus: Düşük gelirli ülkelerde ölüm oranları ile ilgili yaptığı çalışmada Schultz (1993) tarımla geçimini sağlayan kırsal bölgelerde ölüm oranlarının daha yüksek olduğunu, şehirleşmenin nüfusun sağlık durumunu iyileştirdiğini savunmuştur. Tarihsel süreç göz önünde bulundurulduğunda etkisinin yönü zaman ve koşullara göre değişse de, sağlık durumunun belirleyicileri arasında kent ve kırsal nüfus dağılımı önemli yer tutmaktadır.

Çevre Sağllğı, Să̆llk Risk Faktörleri ve Sağllk Hizmetleri/ Temiz Suya Erişim: Birleşmiş Milletler İnsani Kalkınma Raporu (2007- 2008)'na göre, temiz suya erişebilen nüfus oranı, bulaşıcı hastalıkların yaygınlığı gibi değişkenler çevre sağlığı ölçütleri olarak kabul edilmiştir. HIV, AIDS gibi bulaşıcı hastalıklar ve az gelişmiş ülkelerde tüberküloz, sitma gibi hastalıkların yaygınlığı sağlı risk faktörleridir (Çevik, 2013). Kim ve Moody (1992) çalışmalarında temiz suya erişimin bebek ve çocuk ölüm oranları üzerinde iyileştirici etkisi olduğunu bulmuşlardır. Çevik (2013) ise HIV ve tüberküloz hastalıklarının yaygınlığının çocuk ölüm oranlarını artırdığı sonucuna ulaşmışlardır. Bu nedenle sağlık risk faktörleri olarak tüberküloz hastalı̆̆ının yaygınlı̆̆ , kişi başı karbondioksit emisyonu ve temiz suya erişebilen nüfus oranı regresyona dahil edilmiştir.

Yönetişim: Daha önceki çalışmalarda kamu sağlık harcamalarının sağlık sonuçları üzerindeki etkisi ile ilgili çelişkili sonuçlar, kamu kesiminin performansına dikkatleri yöneltmiştir (Çevik, 2013). Kamu kesiminin performansı eğitim, sağlık gibi yarı kamusal malların sunumunu gerçekleştirirken bu alanlarda ne kadar iyileşme sağladığı ile ölçülür (La Porta vd., 1999: 226).

Kurumların kalitesinin, yolsuzluğun ${ }^{5}$ ve kamu sektörünün etkililiğinin sağl1k sonuçları üzerinde direkt etkisinin olduğunu tespit eden birçok çalışma bulunmaktadır (Gupta vd.,2000; Rajkumar ve Swaroop, 2008; Hu ve Mendoza, 2013: 290). Baldacci vd. (2003) düşük yönetişim seviyesinin, kamu harcamalarının kalkınma göstergeleri üzerindeki etkisini düşürdüğünü ifade etmişlerdir. Bu nedenle kamu kesiminin performansını ve kalitesini yansıtması açısından yönetişim indeksleri olarak Kaufmann, Kraay ve Mastruzzi (2004) tarafindan geliştirilen altı tane yönetişim göstergesinden biri olan düzenleyici kalite (regulatory quality) regresyona dahil edilmiştir.

Analizlerde kullanılan bağımlı ve bağımsız değişkenlerin tanımı ve kaynağı Çizelge 5'de, tanımlayıcı istatistikleri ise Çizelge 6' da sunulmuştur.

\footnotetext{
${ }^{5}$ Önemli bir gösterge olan yolsuzluğun sağlığın hizmet sunumunu negatif yönde etkilemesi üç kanal üzerinden açıklanmaktadır (De La Croix ve Delavallade, 2009; Rajkumar ve Swaroop, 2008): rüşvet fiyatları yükselterek birçok kişinin bu hizmetlerden dışlanmasına neden olması, yatırımların beşeri sermaye yerine daha fazla rant sağlayan alanlara kaydırılması, kamu gelirlerinin düşmesi.
} 
Çizelge 5. Bağımsız Değişkenlerin Tanımı, Kaynağı ve Bağımlı Değişken Üzerinde Beklenen Etkisi

\begin{tabular}{|c|c|c|c|}
\hline Değişken & Tanım & Kaynak & Beklenen Katsayı İşareti \\
\hline $\begin{array}{l}\text { Çocuk Ölüm } \quad \text { Oranı } \\
\text { (ÇÖO) }\end{array}$ & $\begin{array}{l}\text { Beş yaş altı çocuk ölüm } \\
\text { oran1. Beş yaşın ulaşmadan } \\
\text { ölmesi tahmin edilen çocuk } \\
\text { sayıs1 ( } 1.000 \text { çocuk baş1) }\end{array}$ & $\begin{array}{l}\text { Dünya Bankas1- World Development } \\
\text { Indicators (2002-2012) }\end{array}$ & \\
\hline Gelir (KBGSYİH) & $\begin{array}{l}\text { Kişi başı gayri safi yurt içi } \\
\text { hasıla. }\end{array}$ & $\begin{array}{l}\text { Dünya Bankas1- World Development } \\
\text { Indicators (2002-2012) }\end{array}$ & Negatif \\
\hline $\begin{array}{l}\text { Kamu } \\
\text { Sağlı Harcamaları } \\
\text { (\%GSYİH) }^{6} \\
\text { (KSHGSYİ) }\end{array}$ & $\begin{array}{l}\text { Gayri safi yurt içi hasılanın } \\
\text { yüzdesi olarak kamu sağlık } \\
\text { harcamaları. }\end{array}$ & $\begin{array}{l}\text { Dünya Bankas1- World Development } \\
\text { Indicators (2002-2012) }\end{array}$ & Negatif \\
\hline Eğitim & $\begin{array}{l}\text { Okula kaydolan öğrencinin } \\
\text { tahmin edilen okullaşma } \\
\text { süresi, ilkokul ve ortaokul } \\
\text { (kadın) }\end{array}$ & $\begin{array}{l}\text { UNESCO-Unesco Institute for } \\
\text { Statistics }(2002-2012)\end{array}$ & Negatif \\
\hline Temiz Suya Erişim & $\begin{array}{l}\text { Temiz içme suyuna } \\
\text { erişebilen nüfus oran1. }\end{array}$ & $\begin{array}{l}\text { Dünya Bankas1- World Development } \\
\text { Indicators (2002-2012) }\end{array}$ & Negatif \\
\hline Tüberküloz & $\begin{array}{l}\text { Tüberküloz hastalığının } \\
\text { yaygınlık oranı (100.000 kişi } \\
\text { baş1) }\end{array}$ & $\begin{array}{l}\text { Dünya Sağlık Örgütü, World Health } \\
\text { Statistics) (2002-2012) }\end{array}$ & Pozitif \\
\hline Kırsal Nüfus & $\begin{array}{l}\begin{array}{l}\text { Kırsal bölgede yaşayan } \\
\text { nüfusun toplam } \\
\text { nüfus } \\
\text { içindeki pay1. }\end{array} \\
\end{array}$ & $\begin{array}{l}\text { Dünya Bankas1- World Development } \\
\text { Indicators (2002-2012) }\end{array}$ & Pozitif \\
\hline Düzenleyici Kalite & $\begin{array}{l}\text { Devletin piyasaya } \\
\text { müdahalesindeki etkinlik ve } \\
\text { performansinı tahmin eden, } \\
\text { değeri }-2.5 \text { ile }+2.5 \text { arasında } \\
\text { değişen, yüksek değeri daha } \\
\text { iyi performansı gösteren } \\
\text { yönetişim indeksi }\end{array}$ & $\begin{array}{l}\text { Dünya Bankas1- World Governance } \\
\text { Indicators (2002-2012) }\end{array}$ & Negatif \\
\hline Gelir Eşitsizliği (GINI) & $\begin{array}{l}\text { Yüksek değerlerinin, yüksek } \\
\text { gelir eşitsizliğini yansıttığı } \\
\text { Gini katsayısı. }\end{array}$ & $\begin{array}{l}\text { Dünya Bankas1- World Development } \\
\text { Indicators (2002-2012) }\end{array}$ & Pozitif \\
\hline 0-14 Nüfus & $\begin{array}{l}0-14 \text { yaş aralığındaki } \\
\text { nüfusun toplam nüfus } \\
\text { içindeki payı. }\end{array}$ & $\begin{array}{l}\text { Dünya Bankas1- World Development } \\
\text { Indicators (2002-2012) }\end{array}$ & Pozitif \\
\hline Kişi başı CO2 emisyonu & $\begin{array}{l}\text { Karbondioksit emisyonu } \\
\text { (kişi başına düşen metrik ton } \\
\text { cinsinden) }\end{array}$ & $\begin{array}{l}\text { Dünya Bankas1- World Development } \\
\text { Indicators (2002-2012) }\end{array}$ & Pozitif \\
\hline $\begin{array}{l}\text { Hukuk Sistemleri (Araç } \\
\text { Değişken) }\end{array}$ & \begin{tabular}{lcl}
\multicolumn{2}{l}{ Anglo-sakson } & Hukuk \\
Sistemi, & Fransız & Hukuk \\
Sistemi, & Alman & Hukuk \\
\end{tabular} & La Porta vd. (1999). & \\
\hline
\end{tabular}

\footnotetext{
${ }^{6}$ Rajkumar ve Swaroop (2008: 99)'un belirttiği üzere çocuk ölüm oranlarını yalnızca t döneminin değil önceki dönemlere ait kamu sağlık harcamaları da etkiler. Yani kamu sağlık harcamalarına ait gecikmeli değerler de analize dahil edilebilir. Ancak bu alanda yapılan birçok çalışma zaman boyutu kısa panellerden oluştuğu için gözlem kaybı olmaması nedeniyle gecikmeli değer kullanmamışlardır. Ancak Rajkumar ve Swaroop (2008) KSHGSYİH (-1) değişkeni eklendiği durumda da katsayılar ve anlamlılıklarının değişmediğini belirtmişlerdir. Bu nedenle, bu regresyonda gecikmeli değer kullanılması tercih edilmemiştir.
} 


\begin{tabular}{|l|l|l|l|}
\hline & $\begin{array}{l}\text { Sistemi, İskandinav Hukuk } \\
\text { Sistemi }\end{array}$ & & \\
\hline $\begin{array}{l}\text { İfade Özgürlüğü ve } \\
\text { Hesap Verebilirlik (Araç } \\
\text { Değişken) }\end{array}$ & $\begin{array}{l}\text { Siyasi haklar, bireysel } \\
\text { özgürlükler, medya } \\
\text { bağımsızlığı, vatandaşların } \\
\text { karar alma sürecine katılımı } \\
\text { gibi göstergeleri barındıran, } \\
\text { değeri }-2.5 \text { ile +2.5 arasında } \\
\text { değişen yönetişim indeksi }\end{array}$ & $\begin{array}{l}\text { Dankas1- World Governance } \\
\text { Indicators (2002-2012) }\end{array}$ & \\
\hline
\end{tabular}

Çalışmada 149 ülkenin 2002- 2012 yıllarına ait verisi kullanılmıştır. Bu yıllara, verilerin geniş bir örneklem üzerinden ülkeler arası karşılaştırma yapabilmeye imkan sağladığı ve önceki çalışmaların sonuçlarıyla mukayese edilebilir olduğu için karar verilmiştir. Çizelge 6 ise değişkenlere ilişkin tanımlayıcı istatistikleri vermektedir.

Çizelge 6. Tanımlayıcı İstatistikler

\begin{tabular}{|l|l|l|l|l|l|}
\hline & Ort. & Max. & Min. & Std. Dev. & Gözlem \\
\hline çöo & 24.44038 & 192 & 2.3 & 32.8557 & 520 \\
\hline kbgsyih & 20680.4 & 96245.49 & 616.8736 & 17410.79 & 520 \\
\hline kshgsyih & 3.77 & 12.60 & 0.03 & 2.17 & 520 \\
\hline kadıneğitimi & 11.31156 & 16.26722 & 2.81115 & 1.902966 & 520 \\
\hline temiz su & 91.82481 & 100 & 36.4 & 12.10525 & 520 \\
\hline gini & 37.4365 & 64.73 & 23.72 & 8.784466 & 520 \\
\hline tüberküloz & 81.30269 & 1660 & 3.4 & 138.8627 & 520 \\
\hline kişi başı co2 & 5.278154 & 24.82465 & 0.022757 & 4.402744 & 520 \\
\hline kırsal nüfus & 36.25566 & 90.383 & 2.313 & 18.80207 & 520 \\
\hline 0-14 nüfus & 23.95525 & 50.12975 & 13.35949 & 9.745651 & 520 \\
\hline düzenleyici kalite & 0.473381 & 1.920921 & -1.73052 & 0.884967 & 520 \\
\hline
\end{tabular}

\subsection{Model ve Tahmin Yöntemi}

Belirli bir zaman dilimine ait yatay kesit verileri biraraya getirmesi sayesinde panel veri kullanmanın, serbestlik derecesini artırmak, birimlere özgü gözlenemeyen-dışlanmış değişkenleri (omitted variables) kontrol altına almak ve bağımsız değişkenler arasında yüksek korelasyon olma olasılığını azaltmak gibi birçok üstünlüğü vardır (Asteriou ve Hall, 2007: 9; Hsiao, 2006: 3- 5). Bu üstünlüklerden yararlanmak üzere, literatürde yer alan birçok yatay kesit veriyle yapılan çalışmadan farklı olarak bu çalışmada, geniş bir dünya örneklemi ve 2002-2012 yılları arasını kapsayan panel veri ile çalışı1mıştır.

Ancak veri setinde eksik gözlemler mevcuttur. Bu nedenle her bir kesit için gözlem sayısı farklı olan "dengeli olmayan (unbalanced)" bir veri seti kullanılmıştır". Tahmin edilecek modelin fonksiyonel şekline literatürde yapılmış çalışmalar (Berger ve Messer, 2002; Filmer ve Pirtchett, 1999; Gupta vd., 2002; Rajkumar ve Swaroop, 2008; Çevik, 2013) dikkate alınarak karar verilmiştir. Diğer çalışmalarla mukayese edilmesinin kolaylaşması ve

\footnotetext{
7 Gözlem sayısının neredeyse yarı yarıya düşmesinin nedeni gelir eşitsizliğinin etkisini görmeye yönelik kullanılan "gini katsayısı" nın çok fazla eksik gözlem içeriyor olmasıdır.
} 
katsayıların esneklik değerlerini yansıtması için logaritmik dönüşüm yapılmış, ancak Filmer ve Pritchett (1999) ve Rajkumar ve Swaroop (2008) çalışmalarında olduğu gibi negatif değer alan yönetişim indeksi (düzenleyici kalite) logaritması alınmadan kullanılmıştır. Diğer ampirik çalışmalardan (Filmer ve Pritchett, 1999; Gupta vd., 2002; Rajkumar ve Swaroop, 2008; Çevik, 2013) yararlanılarak belirlenmiş olan sağlık fonksiyonu tahmin denklemi aşağıdaki gibidir:

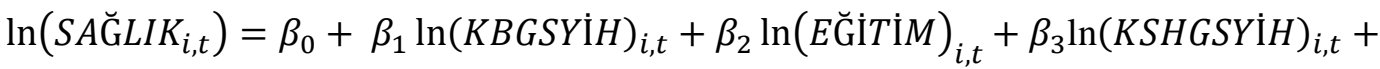

$$
\begin{aligned}
& \beta_{4}(Y \text { ÖNETİŞ่ } M)_{i, t}+\beta_{5}(Y \text { ÖNETISŞ่ } M)_{i, t} * \ln (K S H G S Y \dot{I} H)_{i, t}{ }^{8}+\delta \ln X_{i, t}{ }^{9}+\mu_{i}{ }^{10}+\varepsilon_{i, t}
\end{aligned}
$$

\section{(Denklem 1)}

$i=1,2,3, \ldots \ldots, N t=2002,2003, \ldots ., 2012$

Kullanılacak panel veri modellerinin tahmin teknikleri arasındaki tercih, kullanılan veri seti, modele ilişkin teorik altyapı ve birçok istatistiksel testlere göre belirlenmektedir. Tahmin yöntemine geçmeden önce serilerde yatay kesit bağımlılığının olup olmadığı ve buna göre de serilerin durağanlıkları panel birim kök testleriyle incelenmelidir.

\subsubsection{Yatay Kesit Bağımlıığı}

Yatay kesit bağımlılı̆̆ını test etmek için hangi testin kullanılacağına, veri setinin zaman ve kesit boyutuna göre karar verilmektedir. Bu çalışmada kesit boyutunun (149 ülke), zaman boyutundan (11 y1l) büyük olması nedeniyle, $\mathrm{N}>\mathrm{T}$ durumunda kullanılan ve Pesaran, Ullah ve Yamagata (2008) tarafindan sapması düzeltilmiş CD testi (Bias Adjusted Cross Sectionally Dependence Lagrange Multiplier) kullanılmıştır. Testin hipotezi aşağıdaki şekildedir (Göçer, Mercan ve Hotunluoğlu, 2012: 455 ):

\begin{tabular}{|c|c|c|c|}
\hline CD Test & Değişkenler & Test istatistiği & Olasılık Değeri \\
\hline \multirow[t]{4}{*}{ Bias Adjusted CD Test } & çöo & -0.23 & 0.59 \\
\hline & kbgsyih & -0.96 & 0.83 \\
\hline & kshgsyih & 0.67 & 0.25 \\
\hline & kadıneăitimi & -0.51 & 0.69 \\
\hline
\end{tabular}

$$
\begin{aligned}
& H_{0} \text { : Yatay Kesit Bağımlılığı Yoktur } \\
& H_{1} \text { : Yatay Kesit Bağımlılığı Vardır }
\end{aligned}
$$

\footnotetext{
${ }^{8}$ YÖNETIŞİM* $\ln$ (KSHGSYİH) : yönetişimin kamu sağlık harcamalarının etkililiği üzerindeki dolaylı etkisini görmeye yönelik olarak yönetişim ile kamu sağlık harcamaları arasındaki "interaktif terim".

${ }^{9} \mathrm{X}$ - literatürde yer alan diğer değişkenler vektörü (Çizelge 5 'te yer alan diğer değişkenler).

${ }^{10} \mu_{i}$-zaman içinde sabit, sağlık sonuçlarını etkileyebilecek ülkelere özgü gözlenemeyen etkiler. Seçilen örneklem (dünya ülkeleri) yapısı rassal etkiler modelini işaret etmektedir. E-Views 9.0 paket programı kullanılarak yapılan çalışmada rassal kesit etkilerinin anlamlılığını ölçmeye yönelik yapılan ve EKK tahmininden gelen kalıntılara dayalı Breusch- Pagan (1980) Lagrange Multiplier testine göre (Baltagi, 2005: 60) rassal kesit etkilerin modele dahil edilmesi gerektiği bulunmuştur. Rassal etkiler methodu olarak, modelde kukla değişken olması nedeniyle Wallace-Hussein kullanılmıştır (Atıcı ve Güloğlu, 2006: 15).

${ }^{11}$ Yatay kesit bağımlılı̆̆ı testleri Gauss 10.0 Programı'nda yapılmıştır.
} 


\begin{tabular}{|l|l|l|l|}
\hline & temiz su & 0.74 & 0.23 \\
\cline { 2 - 4 } gini & 2.23 & 0.18 \\
\cline { 2 - 4 } & tüberküloz & -0.13 & 0.47 \\
\hline kişi bașı co2 & 1.22 & 0.12 \\
\hline kırsal nüfus & -0.33 & 0.63 \\
\hline & 0-14 nüfus & 1.01 & 0.10 \\
\hline & düzenleyici kalite & 0.42 & 0.66 \\
\hline
\end{tabular}

Tüm değişkenler için tabloda yer alan olasılık değerlerine bakıldığında 0.05 seviyesinde $H_{0}$ hipotezi reddedilmemekte ve paneldeki birimler arasında yatay kesit bağımlılı̆̆ının olmadığı görülmektedir.

\subsubsection{Panel Birim Kök Testi}

Panel birim kök testleri, yatay kesitler arasında bağımlılık olup olmadığına göre birinci ve ikinci nesil olarak ayrılmaktadır. Serilerde yatay kesit bağımlılığının varlığı reddedildiği için birinci nesil panel birim kök testleri kullanılmalıdır. Ancak birinci nesil panel birim kök testleri de, yatay kesitlerin homojen veya heterojen olmasına göre ikiye ayrılmaktadır: Levin, Lin, Chu (2002), Breitung (2005) ve Hadri (2000) homojenlik varsayımına; Im, Pesaran, Shin (2003), Maddala ve Wu (1999), Choi (2001) ise heterojenlik varsayımına dayanmaktadır (Mercan, 2014: 136). Örneklemin heterojen bir yapıya sahip olması ve serilerde yatay kesit bağımlılığı tespit edilmediği için, $\mathrm{N}>\mathrm{T}$ varsayımına dayanan ve heterojen panel yapısına izin veren Im, Pesaran, Shin (2003) Panel Birim Kök Testi uygulanmıştır. Testin hipotezi aşağıdaki gibidir (Tatoğlu, 2012: 212):

$$
\begin{aligned}
& H_{0} \text { : Birim kök vardır } \\
& H_{1} \text { : Birim kök yoktur }
\end{aligned}
$$

Bu testte olasılık değerlerinin 0'a yakın olması serilerin durağan olduğunu, 1'e yakın çıkması ise birim kökün olduğunu göstermektedir (Hepaktan ve Çınar, 2011: 143).

IPS (2003) Panel Birim Kök Testi sonucu serilerin hepsinin düzey değerinde durağan olduğu tespit edilmiştir. Sonuçlar aşağıdaki çizelgede yer almaktadır.

Çizelge 8. Im, Pesaran, Shin (2003) Panel Birim Kök Testi Sonuçları

\begin{tabular}{|l|l|l|l|}
\hline \multicolumn{1}{|c|}{ Değişkenler } & \multicolumn{1}{|c|}{$\begin{array}{c}\text { Test İstatistiği }(\mathbf{0}) \\
\text { çöo }\end{array}$} & $\begin{array}{c}\text { Olasılık Değeri } \\
\mathbf{I}(\mathbf{0})\end{array}$ & Karar / $\boldsymbol{H}_{\mathbf{0}}:$ Birim Kök Vardır \\
\hline kbgsyih & -4.27 & 0.000 & Ho red \\
\hline kshgsyih & -2.98 & 0.001 & Ho red \\
\hline kadıneğitimi & -5.16 & 0.002 & Ho red \\
\hline temiz su & -21.19 & 0.000 & Ho red \\
\hline gini & -2.01 & 0.000 & Ho red \\
\hline tüberküloz & -2.67 & 0.044 & Ho red \\
\hline kişi başı co2 & -3.30 & 0.025 & Ho red \\
\hline
\end{tabular}




\begin{tabular}{|l|l|l|l|}
\hline kırsal nüfus & -2.46 & 0.007 & Ho red \\
\hline $\mathbf{0 - 1 4}$ nüfus & -3.74 & 0.000 & Ho red \\
\hline düzenleyici kalite & 2.12 & 0.036 & Ho red \\
\hline
\end{tabular}

Not: Sabitli ve trendli modelde gecikme uzunlukları Schwarz bilgi kriterine göre belirlenmiştir.

\subsection{3. İki Aşamalı En Küçük Kareler Yöntemi}

Modelde kullanılan değişkenlerin birbirleriyle olan iliş̧kilerinin teorik altyapısı da yöntem seçiminde etkilidir. Modelde, bağımsız değişken ile bağımlı değişken arasında teorik olarak ters yönlü bir nedensellik ilişkisi beklendiği durumda, bağımlı değişken hata terimi ile ilişkili olacak ve tahminler yanlı olacaktır (Filmer \& Pritchett, 1999: 1313).

$$
\mathrm{Y}=B_{1} X_{1}+B_{2} X_{2}+\ldots+B_{k} X_{k}+u \quad \text { (Denklem 2) }
$$

Denklem 2 'de $\operatorname{Cov}\left(X_{j}, u\right) \neq 0$ olduğu durumda, $X_{j}$ egzojen olmayacağı için EKK tahmincisi tutarlı olmayacaktır. Böyle bir içsellik sorunu karşısında, endojen değişken yerine araç değişken kullanılarak tutarlı parametreler elde edilmesi kolaylaşacaktır (Arı ve Özcan, 2012: 161).

$\mathrm{Bu}$ çalışma açısından bakıldığında, bir ülkede kamu harcamalarının artırılması sağlık göstergelerini iyileştiriyorken, bu göstergelerin kötü olması nedeniyle de kamu harcamalarında artış yaşanıyor olabilir. Böyle bir durumda, kamu sağlık ve eğitim harcamalarındaki varyasyonu açıklayabilecek ancak bağımlı değişkenleri kamu sağlık ve eğitim harcamaları dışında başka bir kanaldan etkileyemeyecek araç değişkenler bularak, kamu harcamalarının iki aşamalı olarak analize dahil edildiği "İki Aşamalı En Küçük Kareler Yöntemi” tercih edilmektedir. Analizlerde kullanmak üzere bu açıklamaya uyan araç değişkenler olarak, Rajkumar \& Swaroop (2008) ve Hu \& Mendoza (2013) çalışmalarında kullanılan "hukuk sistemleri" kullanılmıştır. Bu çalışmalar, hukuk sisteminin, devletin toplum üzerinde daha anlamlı bir rol oynamasını sağlayabileceği ve bu sisteme göre devlet yapısının, merkezileşme ve kamu kaynaklarını dağıtma konusunda güç kullanımını belirleyeceği varsayımına bağlı olarak hukuk sistemlerini araç değişken olarak kullanmışlardır (La Porta et al., 1999; Hu \& Mendoza, 2013: 292). Bu nedenle La Porta et al. (1999) çalışmasında yer alan dört hukuk sistemi kukla olarak olarak kullanılmıştır: İngiliz Hukuku, Fransız Hukuku, Alman Hukuku ve İskandinav Hukuku. Bunlara ek olarak, Hu \& Mendoza (2013) takip edilerek, "ifade özgürlügü ve hesap verebilirlik" indeksi de araç değişken olarak kullanılmıştır.

\subsection{Tahmin Sonuçları ve Yorumlanması}

Temel ampirik sonuçları yansıtması açısından önce EKK tahmini sonuçları, sonra da araç değişken kullanılarak yapılan İki Aşamalı En Küçük Kareler sonuçları Çizelge 9'da sunulmuştur.

Çizelge 9. Tahmin Sonuçları

\begin{tabular}{|l|l|l|l|}
\hline & EKK (1) & EKK (2) & 2 EKK (3) \\
\hline Değişken & $\begin{array}{l}\text { Lnçöo } \\
\text { (t-stat.) }\end{array}$ & $\begin{array}{l}\text { Lnçöo } \\
\text { (t-stat.) }\end{array}$ & $\begin{array}{l}\text { Lnçöo } \\
\text { (t-stat.) }\end{array}$ \\
\hline Inkbgsyih & $-0.28^{* * *}$ & $-0.26^{* * * *}$ & $-0.26^{* * *}$ \\
\hline
\end{tabular}




\begin{tabular}{|c|c|c|c|}
\hline & $(-5.90)$ & $(-5.16)$ & $(-5.93)$ \\
\hline In okullaşma (kadın) & $\begin{array}{l}-0.38 * * * \\
(-3.82)\end{array}$ & $\begin{array}{l}-0.39 * * * \\
(-3.62)\end{array}$ & $\begin{array}{l}-0.38 * * * \\
(-3.56)\end{array}$ \\
\hline lnkshgsyih & $\begin{array}{l}-0.07 * * \\
(-2.16)\end{array}$ & $\begin{array}{l}-0.07 * * \\
(-2.04) \\
\end{array}$ & $\begin{array}{l}-0.07(a) \\
(-0.48)\end{array}$ \\
\hline Ingini & $\begin{array}{l}0.22 * * * \\
(3.24)\end{array}$ & $\begin{array}{l}0.22 * * * \\
(3.25)\end{array}$ & $\begin{array}{l}0.22 * * * \\
(2.88)\end{array}$ \\
\hline Intüberküloz & $\begin{array}{l}0.22^{* * * *} \\
(8.73)\end{array}$ & $\begin{array}{l}0.22 * * * \\
(8.15)\end{array}$ & $\begin{array}{l}0.22 * * * \\
(6.96)\end{array}$ \\
\hline Intemizsu & $\begin{array}{l}-0.69 * * * \\
(-6.06)\end{array}$ & $\begin{array}{l}-0.72 * * * \\
(-6.22)\end{array}$ & $\begin{array}{l}-0.72 * * * \\
(-5.90)\end{array}$ \\
\hline Innüfus(0-14 yaş) & $\begin{array}{l}1.08^{* * *} \\
(13.14) \\
\end{array}$ & $\begin{array}{l}1.07 * * * \\
(12.56)\end{array}$ & $\begin{array}{l}1.07 * * * \\
(6.15) \\
\end{array}$ \\
\hline Inkırsalnüfus & $\begin{array}{l}0.13^{* * * *} \\
(4.77) \\
\end{array}$ & $\begin{array}{l}0.13^{* * * *} \\
(4.11) \\
\end{array}$ & $\begin{array}{l}0.13^{* * *} \\
(4.03) \\
\end{array}$ \\
\hline düzenleyicikalite & & $\begin{array}{l}0.03 \\
(1.09) \\
\end{array}$ & $\begin{array}{l}0.03 \\
(0.63) \\
\end{array}$ \\
\hline In(kshgsyih)*düzenleyicikalite & & $\begin{array}{l}-0.04 * * \\
(-3.31)\end{array}$ & $\begin{array}{l}-0.04 * * \\
(-2.13) \\
\end{array}$ \\
\hline In CO2 tüketimi & $\begin{array}{l}0.10^{* * * *} \\
(3.95) \\
\end{array}$ & $\begin{array}{l}0.09 * * * \\
(3.57) \\
\end{array}$ & $\begin{array}{l}0.09 * * * \\
(2.64) \\
\end{array}$ \\
\hline sabit terim & $\begin{array}{l}3.84 * * * \\
(4.93)\end{array}$ & \begin{tabular}{|l}
$3.92 * * *$ \\
$(4.94)$
\end{tabular} & $\begin{array}{l}3.93 * * * \\
(2.81)\end{array}$ \\
\hline Gözlem & 520 & 520 & 520 \\
\hline R-kare & 0.87 & 0.87 & 0.86 \\
\hline$F$ istatistiği & $\begin{array}{l}381.90 \\
(0.000) \\
\end{array}$ & $\begin{array}{l}309.55 \\
(0.000) \\
\end{array}$ & $\begin{array}{l}302.70 \\
(0.000) \\
\end{array}$ \\
\hline Sargan İstatistiğ $\mathbf{i}^{12}$ & & & $\begin{array}{ll}4.33 & (p- \\
\text { değeri: } & \\
0.3631) & \end{array}$ \\
\hline
\end{tabular}

${ }^{* * *} \mathrm{p}<0.01,{ }^{* *} \mathrm{p}<0.05,{ }^{*} \mathrm{p}<0.1$. Değişen varyans sorunu nedeniyle White düzeltmesi yapılmıştır. $\mathrm{t}$ - istatistikleri katsayıların altında parantez içinde sunulmuştur.

a: Araç değişken olarak hukuk sistemleri kukla değişkenleri ve "ifade özgürlüğü ve hesap verebilirlik" değişkeni kullanılmıştır.
(1) Yönetişim değişkeni olmadan EKK
(2) Yönetişim değişkeni eklenen EKK
(3) İki Aşamalı En Küçük Kareler Yöntemi

\footnotetext{
${ }^{12}$ Kullanılan araç değişkenlerin geçerliliğini test etmek için kullanılan Sargan İstatistiğinin parantez içinde yer alan p-değeri, "araç değişkenler geçerli değildir" hipotezinin \% 1, \% 5 ve \% 10 seviyelerinde reddedildiğini, yani araç değişkenlerin geçerli olduğunu göstermektedir (Davidson ve MacKinnon, 2004).
} 
Herhangi bir gruplandırma yapılmadan 149 ülke için bulunan tahmin sonuçları Çizelge 9'da sunulmuştur. Yapılan analizlerin sonucunda literatürle tutarlı sonuçlar vardır. Bunların başında çevre sağlı̆̆ modelde de çocuk ölüm oranları üzerinde en yüksek etkiye sahip değişkenin 0-14 yaş nüfus oranı olduğu görülmektedir. Üç modelde de istatistiksel anlamlılıklanını koruyan karbondioksit emisyonunda (kişi başı metrik ton), kırsal nüfus oranında ve tüberküloz hastalığına yakalanmış nüfus oranındaki \%100'lük bir artış, çocuk ölüm oranını sırasıyla yaklaşık olarak $\% 10, \% 13$ ve $\% 22$ oranında artırmakta, temiz suya erişebilen nüfus oranındaki \%100'lük bir artış ise çocuk ölüm oranını yaklaşık olarak \%70 oranında azaltabilmektedir.

Kişi başı gelir ve kadın nüfus için beklenen okullaşma yıl sayısı (ilkokul ve ortaokul) bütün modellerde yaklaşık olarak aynı öneme sahip olup, güçlü birer açıklayıcı olarak görünmektedirler.

Gelir eşitsizliğinde \%100 oranında bir artış beklentilerle uyumlu olarak çocuk ölüm oranların $\% 22$ oranında artırmaktadır.

Etkililiği sorgulanan asıl değişken kamu sağlık harcamaları ise, GSYİH içindeki payı olarak analize dahil edilmiştir. Sağlık üretim fonksiyonu için temel model olabilecek EKK (1) modeli, kamu sağlık harcamalarında \%100 oranındaki bir artışın çocuk ölüm oranları üzerinde $\% 7$ oranında bir azalma sağladığını göstermektedir. Kamu sağlık harcamasının katsayısının hala istatistiksel olarak anlamlı olup olmadığını görmek üzere farklı bir değişken olarak düzenleyici kalite değişkeninin dahil edilmesi, kamu sağlık harcamasının etkililiğini değiştirmemiştir. EKK (1) ve EKK (2) modellerinin sonuçlarına göre, çocuk ölüm oranını açıklamakta kadın eğitimi, kişi başı gelir, gelir eşitsizliği ve çevresel değişkenler kadar önemli bir paya sahip olmasa da, kamu sağlık harcamaları etkili görünmektedir. Ancak kamu sağlık harcamaları ile çocuk ölüm oranları arasında olması muhtemel ters nedensellik ilişkisinden ${ }^{13}$ doğabilecek içsellik sorununu göz önünde bulundurmak gerekmektedir. Böyle bir durumda EKK tahmincisi güvenilirliğini yitirecektir. Kamu sağlık harcamalarındaki varyasyonu açıklayabilecek ancak çocuk ölüm oranlarını kamu sağlık harcamaları dışında başka bir kanaldan etkilemesi mümkün görünmeyen dişsal araç değişkenler bulmak gerekmektedir.

Bu açıklamaya uyan araç değişkenler olarak Rajkumar ve Swaroop (2008), Hu ve Mendoza (2013) çalışmalarında da kullanılan "hukuk sistemleri" ${ }^{14}$ " ve "ifade özgürlüğü ve hesap verebilirlik" göstergeleri kullanılmıştır.

Diğer çalışmaları takip ederek başvurulan İki Aşamalı En Küçük Kareler Yöntemi sonuçlarını gösteren 2 EKK (3) modelinin sonuçlarına bakıldığında kamu sağlık harcamalarının katsayısı hala negatif olmasına rağmen istatistiksel anlamlılığını korumadığ görülmektedir. Ancak kamu sağlık harcamaları, kamunun piyasayı düzenlemedeki kalite ve performansını gösteren yönetişim değişkenlerinden biri olan düzenleyici kalite indeksi ile Rajkumar ve Sawaroop (2008)'un kullandığı tekniği takip ederek "interaktif terim" olarak regresyona dahil edildiğinde bu terimin katsayısının negatif ve $\% 5$ ve $\% 10$ seviyelerinde

\footnotetext{
${ }^{13}$ Kamu sağlık harcamalarının artışı çocuk ölüm oranlarını düşürebilir ancak çocuk ölüm oranlarının yüksek olması da devleti kamu sağlık harcamalarını artırmaya itebilir.

${ }^{14} \mathrm{Bu}$ çalışmalara göre ülkelerin hukuk sistemleri, devletin toplum üzerinde daha anlamlı bir rol oynamasını sağlayabileceği ve sisteme göre devlet yapısının merkezileşme ve kamu kaynaklarını dağıtma konusunda güç kullanımını belirleyeceği savunulmaktadır (Hu ve Mendoza, 2013: 292; La Porta vd., 1999). Buna bağlı olarak La Porta vd. (1999)'nin çalışmasında yer alan dört hukuk sistemi (Anglo-sakson Hukuk Sistemi, Fransız Hukuk Sistemi, Alman Hukuk Sistemi, İskandinav Hukuk Sistemi) araç değişken olarak kullanılmıştır.
} 
anlamlı olduğu görülmektedir. Yani kamu sağlık harcamalarının, kamunun piyasayı düzenleyici kalitesinin yüksek olduğu ülkelerde az da olsa etkili olduğu gözlemlenmiştir. $\mathrm{Bu}$ bulgu, Rajkumar ve Swaroop (2008) çalışmasında yönetişimin kamu sağlık harcamalarının etkililiğini artırdığı yönündeki görüşü desteklemektedir.

Literatürde sağlık sonuç göstergeleri üzerindeki etkisine dair birçok çelişkili bulguların yer aldığı kamu sağlık harcamalarının, bu çalışmada yapılan İki Aşamalı En Küçük Kareler yöntemi sonucuna göre tek başına etkili bulunmayışı, yine de tüm dünya ülkeleri için ortak bir çıkarım yapmak için yeterli olmayacaktır. Çünkü böyle bir analiz seçilen örneklem, zaman dilimi ve değişkenlere oldukça duyarlıdır. Ancak teorik bilgilerle ampirik bulgular bir arada değerlendirildiğinde, Çevik (2013)'in çalışmasında olduğu gibi, ülkelerin gelir düzeylerine göre gruplandırılarak ayrı ayrı incelenmesi her grup için farklı sonuçlar çıkmasına neden olacaktır. Yüksek ve yüksek- orta gelirli ülkelerde çocuk ölüm oranlarını düşürmek için gereken koruyucu sağlık hizmetlerinin sunumunun zaten sağlanmış olması, bu ülkelerde kamu sağlı harcamalarındaki artışın, kadın eğitimi, kişi başı gelir ve çevre kirliliği gibi göstergelerdeki artışlardan daha az etkili olmasına neden olabilir. Şekil 3'den görülebileceği üzere düşük ve düşük- orta gelirli ülkelerde sağlık harcamalarında kamunun payının düşük olması, çocuk ölüm oranlarının görece yüksek olduğu bu ülkelerin ihtiyacı olan koruyucu sağlık hizmetlerinin yeterince sunulmadığına bir gösterge olabilir. Bu nedenle "yeniden dağıtım" işlevi olan kamu sağlık harcamalarındaki artışın marjinal etkisi bu ülkelerde daha yüksek olabilecektir.

\section{Sonuç ve Öneriler}

Günümüzde özellikle gelişmiş ülkelerde sağlık harcamalarında kamunun payının oldukça yüksek olduğu görülmektedir. Dolayısıyla kamunun sağlık harcamalarının, sağlık sonuç göstergeleri üzerinde etkili olup olmadığını görmek kaynakların dağılımı gibi sağlık politikaları açısından oldukça değerlidir. Ancak ampirik literatürde yer alan çelişkili sonuçlar, tüm ülkeler için ortak bir çıkarım yapılmasının önüne geçmekte, iktisat teorisi açısından gerekçeleri genel kabul gören devletin sağlığa müdahalesinin, ampirik olarak farklı örneklem, zaman dilimi ve değişkenler ile denenmesine neden olmaktadır. Çoğunlukla yatay kesit veri ile analizler yapan çalışmalardan farklı olarak 2002- 2012 yılları arasında 149 ülkeye ait panel veri kullanılarak yapılmış bu çalışma, literatürle benzerlik gösteren ve göstermeyen bulgulara ulaşmıştır. Asıl odak noktası olan kamu sağlık harcamalarının bu alandaki sonuç göstergelerini iyileştirmedeki etkisi, yani teknik ifadesiyle "etkililiğini" görmek üzere kamu sağlık harcamalarının GSYİH içindeki payı kullanılmış ve ilk iki modelde etkili bulunurken, ekonometrik sorunları gidermek için yapılan İki Aşamalı En Küçük Kareler yönteminde negatif ama istatistiksel olarak anlamlı bir etkiye sahip olmadığ bulunmuştur.

Kamu sağlık harcamalarının etkililiğinin ülkelerin kurumsal kapasitelerine göre farklılık göstereceği varsayımını test etmek için ise, kamunun piyasaya müdahalesindeki performansını yansıtması açısından düzenleyici kalite indeksinin kamu sağlık harcamaları ile interaktif terim olarak kullanılması üzerine, bu terim diğer değişkenlere göre daha düşük etkiye sahip olsa da çocuk ölüm oranlarını düşürmede etkili bulunmuştur. Bu bulgu her ne kadar seçilen örneklem ve zaman dilimi ile sınırlı kalsa da, kamunun piyasayı düzenleyici kalitesinin yüksek olduğu ülkelerde kamu sağlık harcamalarının daha etkili olacağı sonucunu yansıtmaktadır. Bu bulgu ABD ve İngiltere'nin, kişi başı sağlik harcaması, sağlık sonuç göstergeleri ve yönetişim indekslerinin karşılaştırılması ile desteklenebilir. 2013 yılında kişi başı sağlık harcaması (satınalma gücü paritesine göre, sabit 2011 \$) 8987 \$ olan ABD ve 3374 \$ olan İngiltere çocuk ölüm oranı ve doğumda beklenen yaşam süresi (yıl) göstergeleri açısından karşılaştırıldığında İngiltere'nin daha önde dolduğu görülmektedir (Çocuk ölüm 
oranı ve doğumda beklenen yaşam süresi ABD'de sırasıyla 6.9 ve 78.8 değerlerini alırken, İngiltere'de bu değerler sirasıyla 4.6 ve 81.0 olarak gerçekleşmiştir). Bu durum sağllk harcamalarının yüksek olmasının, sağlık sonuçlarını iyileştireceğini garanti etmediğini göstermektedir. Dolayısıyla her ülkenin sağlık politikaları kendi kurumsal yapısı ve hatta gelir seviyesine göre sağlık sonuç göstergeleri üzerinde farklı etkiye sahip olacaktır. 


\section{KAYNAKÇA}

AFONSO, António ve AUBYN, Miguel (2005), "Non-Parametric Approaches To Education And Health Efficiency In OECD Countries," Journal of Applied Economics, Universidad del CEMA, Kasim, s. 227- 246.

ALTAY, Asuman (2007), "Sağlık Hizmetlerinin Sunumunda Yeni Açılımlar ve Türkiye Açısından Değerlendirilmesi”, Sayıştay Dergisi, Sayı 64, Ocak- Mart, s. 33-58.

ANAND, Sudhir ve RAVALLION, Martin (1993), "Human Development in Poor Countries: On the Role of Public Services", Journal of Economics Perspectives, 7 (1), s. 135-150.

ARI, Ayşe ve ÖZCAN, Burcu (2012), "Hollanda Hastalığı: Gelişmekte Olan Ülkeler Üzerine Bir Uygulama", Sosyoekonomi, Temmuz-Aralık, s. 153- 172.

ASTERIOU, Dimitrios ve HALL, Stephen G. (2007), Applied Econometrics: A Modern Approach Using Eviews and Microfit. Revised edition. Palgrave Macmillan, Houndmill, Basingstoke, Hampshire and New York.

ATICI, Cemal ve GÜLOĞLU, Bülent (2006). "Gravity Model of Turkey's Fresh and Processed Fruit and Vegetable Export to the EU", Journal of International Food \& Agribusiness Marketing, 18 (3-4), s. 7-21.

BALDACCI, Emanuele, GUIN-SUI, Maria T. ve DE MELLO, Luiz (2003), "More On The Effectiveness Of Public Spending On Health Care And Education: A Covariance Structure Model", Journal of International Development, Cilt 15, s. 709-25.

BALTAGI, Badi H. (2005), Econometric Analysis of Panel Data, 3.Basım,John Wiley \& Sons.

BERGER, Mark C.ve MESSER, Jodi (2002), "Public Financing of Health Expenditures, Insurance, and Health Outcomes", Applied Economics, Cilt 34, Say1 17, s. 2105-2113

BIDANI, Benu ve RAVALLION, Martin (1997), "Decomposing Social Indicators Using Distributional Data. Journal of Econometrics, 77, s. 125-139.

COASE, Ronald (1960), "The Problem of Social Cost", Journal of Law and Economics, Cilt 3, Ekim, s. 1- 44.

CUTLER, David, DEATON, Angus ve LLERAS-MUNEY, Adriana (2006), "The Determinants of Mortality", Journal of Economic Perspectives, Cilt 20, Say1 3, s. 97 120.

CUTLER, David (1996), "Public Policy for Health Care," NBER Working Papers 5591, National Bureau of Economic Research, Inc.

ÇEVIK, Savaş (2013), "Kamu Sağlık Harcamalarının Sağlık Sonuçları Üzerindeki Etkisi: Ülkelerin Gelir Seviyelerine Göre Bir Karşılaştırma", İstanbul Üniversitesi Siyasal Bilgiler Fakültesi Dergisi, Say1 48, Mart, s. 113-133.

DAVIDSON, Russell ve MACKINNON, James G. (2004), Econometric Theory and Methods, Oxford University Press, New York.

DE LA CROIX, David ve DELAVALLADE, Clara (2009), "Growth, Public Investment And Corruption With Failing Institutions", Economics of Governance, Cilt 10, s. 187- 219.

Declaration of Alma-Ata: International Conference On Primary Health Care, Alma-Ata, USSR, 6-12 $\quad$ Eylül, 1978. http://www.who.int/publications/almaata_declaration_en.pdf?ua=1.

Dünya Sağl1k Örgütü (WHO) (2015), World Health Statistics, WHO Press.

Dünya Sağlı Örgütü (WHO), Global Health Observatory Data Repository, http://apps.who.int/gho/data/node.home, (25.03.2016).

Dünya Bankas1, World Development Indicators, http://databank.worldbank.org/data/reports.aspx?source=world-developmentindicators (10.01.2016). 
Dünya

Bankas1,

Worldwide

Governance

Indicators,http://databank.worldbank.org/data/reports.aspx?source=worldwidegovernance-indicators (08.01.2016).

FEINSTEIN, Jonathan S. (1993), "The Relationship Between Socioeconomic Status And Health: A Review Of The Literature", The Milbank Quarterly, Cilt 71, Say1 2, s. 279322.

FILMER, Deon ve PRITCHETT, Lant (1999), “The Impact Of Public Spending On Health: Does Money Matter?," Social Science and Medicine, Cilt 49, Sayı 10, s. 1309-1323.

FUCHS, Victor R. (1998), "Health, Government, and Irving Fisher," NBER Working Papers 6710, National Bureau of Economic Research, Inc.

GÖÇER, İsmet, MERCAN, Mehmet ve HOTUNLUOĞLU, Hakan (2012), "Seçilmiş OECD Ülkelerinde Cari İşlemler Açığının Sürdürülebilirliği: Yatay Kesit Bağımlılığı Altında Çoklu Yapısal Kırılmalı Panel Veri Analizi”, Maliye Dergisi, Sayı 163, TemmuzAralık, s. 449- 467.

GROSSMAN, Michael (1972), "On the Concept of Health Capital and the Demand for Health," Journal of Political Economy, Cilt 80, Say1 2, Mart- Nisan, s. 223- 255.

GUPTA, Sanjeev, VERHOEVEN, Marijn ve TIONGSON, Erwin R. (1999), "Does Higher Spending Buy Better Results In Education And Health Care?", IMF Working Paper, WP/99/21, Washington, D. C.: International Monetary Fund.

GUPTA, Sanjeev, DAVOODI, Hamid ve TIONGSON, Erwin R. (2000), "Corruption and the Provision of Health Care and Education Services", International Monetary Fund Working Paper, WP/00/116

GUPTA, Sanjeev, VERHOEVEN, Marijn ve TIONGSON, Erwin R. (2002), "The Effectiveness Of Government Spending On Education And Health Care In Developing And Transition Economies," European Journal of Political Economy, Cilt 18, Say1 4, s. 717-737.

GÜNAYDIN, Davuthan (2011), "Sağlık Hizmetlerinde Küresel Reform Yaklaşımları”, Sosyal Siyaset Konferanslarl, $\quad$ Sayı: $\quad 60, \quad$ s. $323-$ 365.http://www.iudergi.com/tr/index.php/sosyalsiyaset.

HEPAKTAN, Erdem ve ÇINAR, Serkan (2011), "OECD Ülkeleri Vergi Sistemi Esnekliğinin Panel Eşbütünleşme Testleri İle Analizi”, Sosyal Bilimler Dergisi, Cilt 5, Say1 2, Ekim, s.133- 153.

HSIAO, Cheng (2006), "Panel Data Analysis - Advantages and Challenges". IEPR Working Papers, Institute of Economic Policy Research (IEPR).

HU, Bingjie ve MENDOZA, Ronald U. (2013), "Public Health Spending, Governance and Child Health Outcomes: Revisiting the Links", Journal of Human Development and Capabilities, Taylor \& Francis Journals, Cilt 14, Say1 2, May1s, s. 285- 311.

JACK, William (2000), "Public Spending On Health Care: How Are Different Criteria Related? A Second Opinion", Health Policy, Cilt 53, s. 61-67.

KAUFMANN, D., KRAAY, A. ve MASTRUZZI, M. (2004), "Governance matters III: Governance indicators for 1996, 1998, 2000, and 2002", World Bank Economic Review, Cilt 18, Say1 2, s. 253- 287.

KIM, Kwangkee ve MOODY, Philip M. (1992), "More Resources Better Health? A CrossNational Perspective", Social Science \& Medicine, Cilt 34, Say1 8, s. 837-842.

KUTZIN, Joseph (2001), "A Descriptive Framework For Country Level Analysis Of Health Care Financing Arrangements", Health Policy, Cilt 56, Say1 3, s. 171-204.

LA PORTA, Rafael, LOPEZ-DE-SILANES, Florencio, SHLEIFER, Andrei ve VISHNY, Robert (1999), "The Quality Of Government", Journal of Law, Economics, and Organization, Cilt 15, Say1 1, s. 222-279. 
MENDOZA, Ronald ve REES, Nicholas (2009), "Infant Mortality During Economic Downturns And Recovery", Working Papers 0904, Unıcef, Division Of Policy And Strategy. "Front Matter." National Research Council. The National Research Council In 1979: Current Issues And Studies. Washington, Dc.

MERCAN, Mehmet (2014), "Ekonomik Büyümenin Belirleyicileri ve 2008 Krizi: Orta Asya Ülkeleri ve Türkiye Ekonomisi İçin Panel Veri Analizi”, Celal Bayar Üniversitesi IIBBF Yönetim ve Ekonomi Dergisi, 21 (1), s. 125-142.

MIKESELL, John L. (2007), Fiscal Administration: Analysis and Applications fort he Public Sector, 7. Basim, Thomson/Wadsworth.

MUSGROVE, Philip (1999), "Public Spending On Health Care: How Are Different Criteria Related?", Health Policy, Cilt 47, s. 207-223

PIGOU, Alfred C. (1952), The Economics of Welfare, New Brunswick, Transaction Publishers.

POTERBA, James M. (1997), "Demographic Structure and the Political Economy of Public Education" Journal of Policy Analysis and Management, Cilt 16, Sayı 1, Kış, s. 4866.

RAJKUMAR, Andrew S. ve SWAROOP, Vinaya (2008), "Public Spending And Outcomes: Does Governance Matter?”, Journal of Development Economics, Cilt 86, s. 96-111.

SAMUELSON, Paul (1954), "Pure Theory for Public Expenditure and Taxation" Review of Economics and Statistics, Cilt 36, Say1 4, s.387-389.

SCHULTZ, T Paul (1993), "Mortality Decline in the Low-Income World: Causes and Consequences", American Economic Review, Cilt 83, Sayı 2, May1s, s. 337- 342.

SELF, Sharmistha ve GRABOWSKI, Richard (2003), "How Effective is Public Health Expenditure in Improving Overall Health? A Cross-country Analysis", Applied Economics, Cilt 35, Say1 7, s. 835-835.

STIGLITZ, Joseph E. (2000 ), Economics of the Public Sector, 3. Basim, W. W. Norton \& Company.

TANZI, Vito (1997), "The Changing Role of the State in Economy: A Historical Perspective", IMF Working Paper/No.97/114.

TANZI, Vito (2009), "The Economic Role of the State Before and After the Current Crisis", Plenary Session of the 65th Congress of the International Institute of Public Finance, 13 Ağustos, Cape Town, Güney Afrika.

TATOĞLU, Ferda (2012), Panel Veri Ekonometrisi, Beta Basım Yayım Dağıtım A.Ş.: İstanbul.

TILAK, Jandhyala B. G. (2008), "Higher education: a public good or a commodity for trade? Commitment to higher education or commitment of higher education to trade?", Quarterly Review of Comparative Education, Cilt 38, Say1 4, Aralı, s. 449466.

TUNCER, İsmail ve YÜKSEL, Cihan (2011), "Kamu Harcamalarının Ekonomik Analizi”, Kökocak, Abdülkadir (Ed.), Kamu Ekonomisi, Ekin Yayınevi, Bursa, s. 213-275.

UNESCO-Unesco Institute for Statistics, http://data.uis.unesco.org/index.aspx?queryid=147 (10.01.2016).

United Nations Development Programme, Human Development Report (2007/ 2008), Palgrave Macmillan.

WILKINSON, Richard G. (1992), "Income Distribution and Life Expectancy", British Medical Journal, Say1 6820, Ocak, s. 165-168.

YILMAZ, Volkan ve YENTÜRK, Nurhan (2015) “Türkiye'de Sağlık Harcamalarına Tarihsel Bir Bakış", İstanbul Bilgi Üniversitesi Sivil Toplum Çalışmaları Merkezi, Kasım. 
YURDADOĞ, Volkan (2007), “Türkiye'de Sağlık Harcamalarının Finansmanı Ve Analizi”, Çukurova Üniversitesi Sosyal Bilimler Enstitüsü Dergisi, Cilt 16, Sayı 1, S.591-610. 